\title{
Institutional Transplant and Cultural Proximity: Evidence from Nineteenth-Century Prussia*
}

\author{
Giampaolo Lecce $^{\dagger}$ and Laura Ogliari ${ }^{\ddagger}$
}

This version: March 2019

${ }^{*}$ We thank the co-editor Dan Bogart and two anonymous referees for comments that helped substantially to improve the article. We are grateful to Alberto Alesina, Maristella Botticini, Rosario Crinò, Francesco Giavazzi and Guido Tabellini for their invaluable supervision; Tommaso Aquilante, Davide Cantoni, Michela Carlana, Italo Colantone, Laura Doval, James Fenske, Nicola Gennaioli, Gunes Gokmen, Carl Hallmann, Christopher Koenig, Eliana La Ferrara, Joel Mokyr, Tommaso Nannicini, Tommaso Orlando, Santiago Maria Perez Vincent, Nicola Persico, Pierre-Charles Pradier, Severine Toussaert and Ludger Woessmann for their useful comments, suggestions and fruitful discussions; and participants of the ASREC 2017, CESifo Workshop on Political Economy, Econometric Society European Winter Meeting 2016, Oxford Development Economic Workshop and EDGE Jamboree, and seminars at Università Bocconi, Yale University and Birmingham Business School. We gratefully acknowledge financial support from the Cowles Foundation for Research in Economics, Fondazione Cariplo and Università Bocconi.

${ }^{\dagger}$ Giampaolo Lecce is a Postdoctoral Fellow ath the Department of Economics of Northwestern University, 2211 Campus Dr, Evanston IL 60208, USA (email: giampaolo.lecce@gmail.com)

${ }^{\ddagger}$ Laura Ogliari is a Postdoctoral Research Fellow at the Department of Economics Management and Quantitative Methods (DEMM) of the University of Milan, Via Conservatorio 7 20122, Milan, Italy (email: laura.ogliari@unimi.it). 


\section{INSTITUTIONAL TRANSPLANT AND CULTURAL PROXIM- ITY: EVIDENCE FROM NINETEENTH-CENTURY PRUSSIA}

This paper presents evidence that cultural proximity between the exporting and the receiving countries positively affects the adoption of new institutions and the resulting long-term economic outcomes. We obtain this result by combining new information on pre-Napoleonic principalities with county-level census data from nineteenth-century Prussia. We exploit a quasi-natural experiment generated by radical Napoleonic institutional reforms and the deeply rooted cultural heterogeneity across Prussian counties. We show that institutional reforms in counties that are culturally more similar to France, in terms of religious affiliation, generate better long-term economic performance.

\section{INTRODUCTION}

Economists have long argued about the importance of good institutions for economic growth. Rule of law, better enforcement of contracts, and secure property rights are usually associated with better economic outcomes, such as higher investment in physical and human capital and technological progress. Some countries lacking good legal institutions have attempted to import them from abroad with the goal of boosting economic growth. However, the adoption of good foreign institutions does not always lead to positive economic outcomes.

What are the elements of successful institutional transplants? In principle, the effectiveness of transplanted formal institutions hinges on their reception by local communities. Shared values, language, ethnicity and religion - collectively defined as cultural proximity - play a relevant role for at least three reasons. First, the new institutions, imbued with the values of the exporting country, could be better tolerated inasmuch as their content resembles the customs and social norms of the receiving communities. ${ }^{1}$ Second, irrespective of the content of the new rules, the receiving country may be more accommodating of institutions from closer and more familiar exporting countries. Finally, a given exporter may adopt a friendlier approach, engaging elites and local populations in the reform process and making the new institutions more acceptable, in more culturally similar receiving countries.

We investigate the economic consequences of the interplay between new institutions and cultural proximity by exploiting a well-known historical natural experiment: the Napoleonic invasion of German terri-

\footnotetext{
${ }^{1}$ In a relevant paper, Dal Bo et al. (2010) set up an experiment and argue that policies and rules are more effective - triggering private cooperation - when they are chosen democratically by the subjects than when they are exogenously imposed. Similarly, greater cooperation from subjects is likely if the imposed rule is perceived as familiar rather than foreign. For example, when US law was imposed in California after it was annexed, Mexican law continued to be de facto applied. Indeed, Californians perceived US law as foreign and distant from their social norms and traditions. Other interesting examples can be found in Mailath et al. (2016).
} 
tories and the consequent imposition of French institutions. Our novel finding is that transplant of these institutions had heterogeneous effects on economic performance across German areas characterized by different degrees of cultural proximity with France. Transplanting French institutions was more effective in areas that were culturally closer to France, while it had virtually no effect in culturally distant territories. This result highlights the relevance of the interplay between culture and institutions for economic development, and it provides the first evidence that cultural proximity plays an essential role in transferring an institution from its original environment to a different context.

To investigate the effects of the interaction between cultural proximity and French institutions, we first zoom in on nineteenth-century Germany with a detailed historical discussion on the modernizing reforms, the differences in their adoption and their economic effects. Then, we build a novel, hand-collected dataset on pre-Napoleonic principalities, their rulers and the adoption of progressive reforms and then complement it with rich county-level information from different waves of the Prussian census. We use religious affiliation as our baseline measure of cultural distance to France. Since countries that share a religion are expected to have similar cultures (see Guiso et al., 2009 and Fisman et al., 2017), we exploit the fact that France was predominantly Catholic at that time and use the share of Protestants in the population as an inverse measure of cultural proximity with France. We corroborate our results by constructing two alternative cultural distance measures. First, we focus on a salient dimension of culture, language, and we exploit linguistic heterogeneity to build a measure of linguistic distance from the French language. Second, we construct a proxy based on hand-collected data that exploits pre-Napoleonic linkages by capturing rulers' familiarity with French culture.

We find evidence that cultural distance is crucial for the long-run economic success of institutional transplants. In particular, the effect of good institutions is positive only in culturally close counties. A one-standard deviation increase in cultural distance, measured as the share of Protestant population in a county, decreases the wages of primary school teachers (our main proxy for economic performance) by approximately $8 \%$ in counties that received French institutions. Indeed, this is a sizable effect since there is no positive impact of French radical reforms in counties with a Protestant share of approximately 70\%, and almost half of the subsample of invaded territories has a Protestant share higher than $70 \%$. Moreover, in culturally similar areas, the positive effect of good institutions increases with the intensity of French domination and with the number of progressive reforms implemented. In contrast, we find no effect in culturally distant territories, irrespective of the intensity of the institutional treatment. Finally, we find that cultural proximity is at least as important in moderating the long-run economic effects of transplants as the alternative channels proposed in the literature, such as state capacity, institutional proximity, religious and linguistic fractionalization and Napoleonic war severity.

Our paper contributes to the literature investigating the importance of good institutions for economic 
growth. Starting with the seminal work of Douglass North (1990), many scholars have emphasized that institutions "matter".2 Specifically, our paper contributes to the historical debate on the effect of the Napoleonic institutions on the invaded territories during Napoleonic military campaigns. Among these studies, Daron Acemoglu et al. (2011) is most closely related to this paper, as it is the first to exploit variation in institutional reforms during the Napoleonic campaigns in eighteenth- and nineteenth-century Germany to quantify the economic impact of radical reforms. ${ }^{3}$ Michael Kopsidis and Daniel Bromley (2016) challenge the econometric analysis offered by Acemoglu et al. (2011), claiming that the institutional reforms have been incorrectly dated and emphasizing the role of coal production as one of the main drivers of economic growth in nineteenth-century Prussia. ${ }^{4}$ In contrast to the existing contributions, our analysis does not focus on the positive effects of adopting good institutions but on the heterogeneity of their reception due to underlying cultural traits and on the resulting differences in long-term economic outcomes. Our paper is broadly consistent with both Kopsidis and Bromley (2016) and Joachim Zweynert (2011). These works caution against the easy interpretation that "big-bang" radical institutional change might be the only way to development. Our result that new institutions have different long-term effects depending on the local environment contributes to the debate on shock therapy, offering evidence in favor of Dani Rodrik (2007)'s thesis that reform programs must avoid a "one size fits all" strategy but should try to account for the specific conditions of time and space and the participation of local actors.

Our work speaks to the historical literature on the developments spurred by the Napoleonic power in Germany between the French revolution and the first half of the nineteenth century. In particular, Elisabeth Fehrenbach (2008) discusses how the Napoleonic domination determined the end of the ancien regime in German states and how the new set of laws implemented by Napoleon triggered a wave of reforms in Prussia. Similarly, Christopher Clark (2007) remarks on how the Napoleonic shock was the catalyst for extensive social and political reforms in the first decades of the nineteenth century. Richard Tilly (1966) stresses how the new socio-political context, among other important factors, led to a more favorable governmental attitude toward industrial development when describing the Prussian industrialization process during the nineteenth century. Finally, Reinhart Koselleck (1967) describes the role of the Prussian bureaucracy in promoting economic development and social reforms as a reaction to the Napoleonic domination. We provide evidence on the direct impact of Napoleonic reforms on economic development and provide systematic empirical evidence on the effects of cultural differences on long-term economic performance.

Finally, our work is also connected to two additional strands of research. First, it relates to the lit-

\footnotetext{
${ }^{2}$ See, for example, Acemoglu et al. (2001, 2002). On the relations between institutions and the legal origins of countries, see Glaeser and Shleifer (2002) and La Porta et al. (2008).

${ }^{3}$ See also Acemoglu et al. (2012), Buggle (2016), Donges et al. (2017) and Keller and Shiue (2016).

${ }^{4}$ In line with the criticism of Kopsidis and Bromley (2016), we use a dummy variable that equals one if the territory saw the presence of Napoleon either as an annexation of the French empire or as a satellite state to measure the institutional change. We do this to avoid any error in the timing of the reforms. Moreover, we always include a control for the presence of coal deposits in our specification.
} 
erature on the transplantation of legal systems (Berkowitz et al., 2003a,b). While these studies focus on the effectiveness of imported legal institutions and attribute differences in their adoption to the process of lawmaking and the demand for law, we test the channel of cultural distance as a moderating factor in the reception of transplanted institutions. Second, our paper is related to the emerging literature on the interplay between culture and institutions. While the individual roles of culture and institutions on economic outcomes have been widely investigated (see Alesina and Giuliano, 2015 for a survey), studies on the interaction between these two drivers remain scant. We analyze the long-term economic effects of the interplay between new legal institutions and local cultures and we empirically show that cultural proximity generates complementarities between local cultures and transplanted institutions, thereby enhancing economic performance.

\section{HISTORICAL OVERVIEW}

\section{Napoleonic Military Campaigns}

The emergence of revolutionary France as an aggressive and strong military power at the end of the eighteenth century marked the end of the Holy Roman Empire. The first victories of the French army created a power vacuum in the central German territories, which Napoleon exploited to create a cordon sanitaire between France and its traditional Eastern enemies: Austria and Russia. By 1795, Napoleon was in control of the left bank of the Rhine, which was formally annexed by the French Empire in the treaty of Luneville (1801). ${ }^{5}$ When the House of Habsburg ceded some of its German estates to Napoleon's allies in 1805, the end of the Holy Roman Empire was essentially determined. The following year, central Germany was unified as the Confederation of the Rhine, a formally independent confederation of sixteen states whose protector and unofficial ruler was Napoleon. ${ }^{6}$ French expansion continued until Napoleon's downfall after the Russian campaign in 1812. By that time, the French sphere of influence extended to Poland (with the creation of the Duchy of Warsaw in 1807) and Northern Germany (with the annexation of the Hanseatic cities of Hamburg, Lubeck, and Bremen in 1810). By the first decade of the nineteenth century, Napoleon

\footnotetext{
${ }^{5}$ According to Fisher (1903), this treaty has also been called the 'First Revolution of Germany' given that a "territory of 150,000 square miles, peopled by 3,500,000 inhabitants, and amounting to about a seventh part of the population and territory of the whole Empire was transferred to foreign non-German powers" (p. 38).

${ }^{6}$ The members of the Confederation promised to "supply their protector with a military contingent of sixty-three thousand men"(Lefebvre, 1969, p. 207), and in return for their support, they were given higher status or territories. For example, the free cities of Augsburg and Nuremberg were annexed by Bavaria. Frankfurt was assigned to Karl von Dalberg, and Nassau became a duchy. Additionally, Dalberg became Prince Primate of the Confederation of the Rhine.
} 
had taken over the majority of German states. ${ }^{7}$ Napoleon's expansion of the French Empire was mainly driven by ideological and geopolitical concerns rather than by the economic outlook of the region. In addition to the desire to maintain influence over a buffer region separating France from the two main Eastern powers, the revolutionary rhetoric of France's natural borders drove his military campaigns. ${ }^{8}$ Accordingly, we will exploit the quasi-natural shock of the Napoleonic invasions to identify the effect of institutional transplants. We will carefully discuss and test the assumption of the economic exogeneity of the French military campaigns in section .

\section{The Imposition of French Institutions}

Despite the marked institutional heterogeneity of the Holy Roman Empire resulting from high territorial fragmentation, some useful general features can be identified. At the dawn of the nineteenth century, the institutions of the ancien regime still pervaded German territories, and feudal privileges were the norm. In rural areas, peasants were subject to several restrictions and burdened by a list of duties and services they had to provide to their lords, even in areas where serfdom had been abolished. In the cities, guilds regulated access to different trades, often limiting the development and growth of the industry they controlled. ${ }^{9}$ Equality before the law was still far from the reality: members of the aristocracy, clergy, and military benefited from particular exemptions, while other groups were discriminated against (e.g., Jews).

The arrival of Napoleon was a disruptive force. His rule over central Europe meant the imposition of a series of radical institutional reforms that aimed at sweeping away old powers and granting him legitimacy. ${ }^{10}$ French rule implied civil equality, religious liberty, the abolition of feudal rights, the sale of Church property, the suppression of corporations, a constitution carrying the right to vote taxes, a more efficient model of administration and the implementation of fiscal reforms that introduced budgeting and the rationalization of public expenditures. All these reforms were intended to create a framework for a European civilization based on French supremacy that would consolidate the Continent's political unity.

\footnotetext{
${ }^{7}$ Figure A1 in Appendix A1 shows the counties in territories controlled by Napoleon differentiating between annexed areas and satellite states in our sample.

${ }^{8}$ Discussions of the Rhine question began well before hostilities broke out in 1792 . The idea of France's natural borders became prominent among Jacobin revolutionaries. On January 21, 1793, Georges Jacques Danton argued in favor of the annexation of Belgium during a national convention saying, "the limits of France are marked by nature, we will reach the four corners of the horizon, to the edge of the Rhine, to the edge of the ocean, to the edge of the Pyrenees, to the edge of the Alps. The boundaries of our Republic must be there". For more details, see Smets (1998).

${ }^{9}$ In the Rhenish area, for example, guilds imposed strict limitations on the adoption of new technologies (Kisch, 1989).

10 "[I]t was important that he, his vassals and his allies should all hold undisputed sovereignty. Any intermediate bodies, privileges or feudal rights must therefore be swept away, so that all men should become directly subject to the state. It was also advisable for the laws of succession to reduce the size of the great fortunes, so making the aristocracy subordinate to the sovereign, and the priests his officials" Lefebvre (1969)
} 
The Civil Code embodied the essentials of this policy, and that is why Napoleon made such vigorous efforts to introduce it everywhere.

While in the annexed territories, the reforms were swiftly and faithfully implemented, in the vassal and allied states, the modernizing reforms were not homogeneously adopted. ${ }^{11}$ For example, Napoleon cared particularly about the newly formed kingdom of Westphalia, and he wished it to become the Napoleonic model state in Germany. Accordingly, the institutional reforms were introduced from the start and thoroughly applied there. In contrast, the modernization process was slower and incomplete in the Grand Duchy of Berg, where many reforms were implemented late (e.g., the Civil Code was introduced only in 1811), and some of them were diluted (e.g., despite the peasant protests, Napoleon conceded the maintenance of land dues to the local aristocracy). In the other states of the Confederation of the Rhine, allied princes adopted at least part of the Napoleonic system. Indeed, the historical circumstances determined by the sudden increase in the area of the largest states - coming from Church possessions, mediatised lands and former free cities - created the need to merge together a number of differing institutions, privileges and religious confessions, and French institutions were considered a suitable tool to gain legitimacy. Conversely, in the Grand Duchy of Warsaw, Napoleon had to come to terms with the extremely great power of the nobility. In trying to get the aristocracy on his side, Napoleon only partially implemented the set of reforms: he gave the constitution that had proclaimed civil liberty and abolished serfdom and introduced the Civil Code, but the land continued to belong to the nobles, and feudal rights, land dues, and forced labor continued to exist. Finally, the timing of the implementation of the reforms and the extent of their adoption also depended on the success of the French military campaigns and on the duration of the French rule. In the northern territories annexed in December 1810, although Napoleon swiftly introduced the French regime, annexation was extremely short-lived, and the advantages of the reforms were counterbalanced by the negative effects of the Napoleonic Blockade.

\section{Prussia and the French Institutions}

The new rulers and the imposed French institutions also generated a revolution from the outside in the German states that were not under the (direct or indirect) influence of French rule. Zweynert (2011) emphasizes how both southwestern Germany and Prussia implemented a "defensive modernization" triggered by external pressure exerted by Napoleon. Similarly, Fehrenbach (2008) remarks that the Prussian reformers favored a defensive modernization against Napoleon.

The military collapse against Napoleon's Grande Armee in 1806 left the country in a difficult position

\footnotetext{
${ }^{11}$ For recent work on the differential implementation of the progressive reforms, see, among others, Arvind and Stirton (2010)
} 
but it was crucial for the Prussian political agenda both in terms of foreign policy and internal reforms. ${ }^{12}$ Prussian ministers realized that, in addition to a pervasive military reorganization, social and economic reforms were needed to keep pace with the efficiency of the French state and to regain status as a great power. They tried to pursue enlightened social and economic reforms but encountered the resistance of the elites and managed to accomplish only a form of "conservative modernization", still oriented toward the old society of estates, the traditional institutions and corporative liberties under the Holy Roman Empire. Indeed, Philip Dwyer (2000) claims that Karl August von Hardenberg, Prime Minister of Prussia, realized the importance of the liberal economic and social principles as an essential precondition for Prussia's economic growth. Consistently, his legislation aimed at abolishing the remnants of aristocratic privileges in Prussia and liberalizing the economy. However, Hardenberg's attempt to change the traditional social order provoked a series of protests and the strong opposition of social elites, which forced the government to back down from many of its original plans. ${ }^{13}$

The effectiveness of the Prussian social and economic reforms has been questioned by historians. Zweynert (2011) describes Prussian defensive modernization as a "limited system change in order to prevent a greater upheaval of the political, social and economic power structure". In the same spirit, Karen Hagemann (2015) writes that the immediate effects of most Prussian reforms implemented in the aftermath of the Napoleonic wars were limited or imposed new burdens to the broader population.

The scope of defensive modernization seems to be more limited than the far-reaching reforms introduced in the largest states of the Confederation of the Rhine or in the annexed territories where the entire structure of the state was overhauled. Indeed, it seems that Napoleon's complete removal of the privileges provided by imperial institutions was a necessary - albeit not sufficient — condition to implement a broad set reforms that could be potentially growth-enhancing. Consequently, in our analysis, we will consider territories that were not under the (direct or indirect) control of Napoleon as the control group while territories under French domination as treated territories.

\section{CULTURAL PROXIMITY AND HETEROGENEOUS ADOPTION}

It is not surprising that each territory under the control of the French Empire had a diverse response to the new imposed institutions, given the different levels of economic, political and cultural development

\footnotetext{
${ }^{12}$ By the peace of Tilsit, Prussia had to pay massive reparations that represented one-third of the monarchy's revenues. Moreover, Prussian territory was cut by half with the loss of everything west of the Elbe to Westphalia and a sizable mass to the east that became the Grand Duchy of Warsaw.

${ }^{13}$ A prominent example is the Gendarmerie-Edikt of 30 July 1812, which brought the lowest tier of administration under the control of government-appointed officials. This was perceived as a direct challenge to the authority of the nobility over their localities and generated a furious outburst of noble opposition to the measure. In the end, the Gendarmerie-Edikt was never implemented but instead was superseded (in 1816) by a new measure that reinforced noble control over the countryside.
} 
characterizing German polities. ${ }^{14}$ For example, Michael Broer (1996) underlines that some local communities were less compatible with the new institutions. He classifies territories under the control of Napoleon in the "inner empire" (territories ruled by Napoleon before 1807) and the "outer empire". In the "inner empire", Napoleonic rule was most effective in transforming the existing structures and left a profound institutional legacy that remained after Napoleon's fall. Countries in the "outer empire" were less adaptable to Napoleonic change, and their societies were less amenable to acculturation than were those in the "inner empire"; hence, the implementation of the new institutions was not as successful in those areas.

Although a complex mix of factors is likely responsible for the heterogeneity in the adoption of the new set of rules across German states, our analysis points at cultural distance from France as a key ingredient for the long-term success of the institutional transplant. In the remainder of this section, we discuss and provide anecdotal evidence on three possible explanations whereby culture generates observable differences in the adoption of foreign institutions. We provide a special focus on religious affiliation, an important and easily identifiable cultural trait that influenced the response to the new institutions.

\section{Cultural proximity and predisposition of the invaded populations}

Similar languages, same religion and analogous social norms are usually associated with social interaction and may induce people to be more accommodating toward "familiar" invaders and the institutions they bring. Indeed, in territories historically more dissimilar to France, as were the ones with a Protestant majority, the imposition of a new set of institutions by a foreign ruler was seen as an act of usurpation, and it encouraged obstructionism. As noted by Margaret Barber Crosby (2008), “[the imposition of foreign law] constituted tyranny in German-speaking Europe, and, according to the evangelical legal thought, which had been handed down from the Reformation, Christians not only had the right to resist, but had the obligation to resist according to Lutheran scriptural interpretation". Conversely, Stuart Woolf (2002) emphasizes how collaboration by Catholic bishops and clergy was successful in forging popular consensus for the French institutions, especially in principalities with an earlier reforming tradition (e.g., Rhineland and Bavaria). For example, parish priests used their influence to boost conscription among peasants and taught the imperial catechism, thereby favoring the legitimacy of the new rules.

In addition, in territories where French customs were more familiar, such as those close to the French border, social and institutional assimilation was somewhat easier. Anecdotal evidence from the Rhineland documents an astonishingly large number of mixed marriages of French speakers and Germans dur-

\footnotetext{
${ }^{14}$ Indeed, the cultural heterogeneity is remarked by Rowe (2003), who notes that "cultural diversity was acceptable in the eighteenth-century Rhineland. It was unwelcome to revolutionary state-builders. The French interior minister, visiting in 1798, was shocked by the numerous customs that confronted him, and which he blamed for obstructing the fusion of the various parts of these diverse countries into a completely republican single whole'. The old territorial divisions were so great as to utterly confuse revolutionary commissioners posted to the region. For them, the imposition of cultural and above all linguistic uniformity was not merely a question of administrative efficiency".
} 
ing French rule. According to Michael Rowe (2003), the "examination of 450 marriage certificates from Koblenz, spanning the period September 1798 to September 1802, reveals that one in seven marriages in the city was mixed, with 61 Frenchmen and two French women marrying Rhinelanders". This unusual number of intermarriages is evidence of both frequent interactions and an absence of extreme animosity against the French, making culturally close territories a more favorable environment for the adoption of new institutions. ${ }^{15}$

\section{Cultural proximity and attitudes of the invader}

The second related mechanism is linked to the different attitudes of the French during the Napoleonic campaigns. The process of state formation in the annexed territories and that of Frenchification in the satellite states entailed the imposition of French norms and practices. Frenchification, however, was not carried out homogeneously across territories. In the early occupied Catholic areas, for example, French representatives were especially cautious in the application of revolutionary decrees. Woolf (2002) notices that in the Rhineland, the days chosen for the revolutionary public holidays were those of popular religious holidays. This careful approach surely favored the compliance of the local population with the new rules.

To facilitate the creation of a more homogeneous national identity, the invaders also used a friendlier approach in the implementation of reforms in territories they considered to be more similar. Again, in the case of the Rhineland, the neighboring Alsatian bilingual Frenchmen were favored in several public appointments to create a natural bridge between French and German culture and to facilitate the integration of the new region into the French Empire. However, the French did not implement this gentle approach in the annexed Italian territories since they considered Italian elites and nobles to be lazy and soft and the common Italians to be uncivilized. ${ }^{16}$ To facilitate the adoption of the institutions, French rule was often more flexible in the Rhineland, a land that was culturally closer to France. ${ }^{17}$ In addition to engaging local elites, Paris promoted policies to actively favor the assimilation process. One of these policies set aside 6 million francs of nationalized land for five veterans' camps in the Rhineland and north Italy (law of 1 Floreal XII, 20 April 1804), where French veterans were required to farm their own land and form a home guard in times of crisis and were encouraged to marry local girls (Rowe, 2003).

Another distinguishing aspect of the French cultural homogenization was the emphasis on social interaction and sociability in general. One prominent example of sociability intentionally diffused by the French regime was Freemasonry. This formal association was populated by relevant French administrators and local notables, providing a fertile ground for the interaction between the invaders and local elites.

\footnotetext{
${ }^{15}$ Intermarriage also helped attenuate language diversity, one of the main obstacles encountered by the French during the Frenchification process.

${ }^{16}$ For a thorough discussion, see Parsons (2010).

${ }^{17}$ For example, when the police minister complained that foreigners (i.e., native Prussians) served as officials in the Rhineland, he was told by the justice minister that many non-Frenchmen were employed there and that they had obtained the "confidence" of the government.
} 
French Freemasonry often followed the path of the victorious military campaign, and army officers created new lodges in French-controlled Europe jointly with local people. In the Rhineland, the number of lodges rose from three to seventeen, with 170 French and 345 local members. In the Grand Duchy of Warsaw, where Freemasonry was historically an important institution, this association played a remarkable role in guaranteeing the collaboration of the Catholic clergy with the new administration. However, the diffusion of Freemasonry was not uniform across all territories under Napoleonic control: in Bavaria, for example, freemasonry was strictly forbidden. ${ }^{18}$

The anecdotal evidence suggests how the French adopted different behaviors in different territories, being more lenient and inclusive towards the populations they deemed more similar. A higher level of engagement of the locals could then translate into higher acceptance of the new institutions.

\section{Cultural proximity and the content of the new institutions}

The final explanation relates to a possible clash generated by the difference between the norms embedded in the new French institutions and the pre-existing local social norms and values. "Napoleon's attempt to oblige ordinary Germans to live according to an Alltagsleben (everyday life) reorganized by French private law, in the form of the Code civil, probably did as much as anything else to encourage the determination of Germans to take up arms and push the French back across the Rhine"(Crosby, 2008). Along the same lines, Geoffrey Ellis (2003) recognizes that the Napoleonic Civil Code conflicted with local customs and vested interests of pre-revolutionary elites. This is especially true in the rural areas, where the local nobles benefited from a strong traditional status and the seigneurial system was deeply rooted. ${ }^{19}$ In the case of Hesse in the Kingdom of Westphalia (and other old Prussian provinces), the peasantry had the most to gain from the new principles imposed by the French government, but in these men, strong ties with a feudal system and the sentiment of loyalty to the ancient regime outweighed the abolition of labor services and generated a sense of discontent. ${ }^{20}$ The French recognized the complexity of exporting an entire system, "[They] acknowledged that the imposition of so comprehensive a new set of rules would inevitably clash with many established practices, which had emerged from and expressed often long-accepted values" (Woolf, 2002).

A clear instance of a clash between the content of the new rules and well-established norms is provided by the different reactions of Catholic and Reformed churches to the reform of the structure of authority within religious institutions. In line with the rationalization of the civil society, Napoleon sought to simplify the organization of the Churches, reducing the number of parishes and bishops according to the size of the population of the departments and imposing an hierarchical structure to their organization.

\footnotetext{
${ }^{18}$ See Woolf (2002) for more details.

${ }^{19}$ Parsons (2010) underlines how in Italy, the new rule "imposed French values and culture on an uncomfortable populace".

${ }^{20}$ See Fisher (1903) for a more complete description of the social dynamics in Hesse.
} 
While Catholics yielded to this simplifying reform, for Protestants, this reorganization "fundamentally contradicted the proud insistence on independence of each community and the egalitarian participation of clerics and faithful which lay at the core of the maintenance of their identity in hostile environments" (Woolf, 2002).

Cultural proximity with France may also have played a role since some of the norms in the Civil Code were entrenched in traditional French values. William Smithers (1901) argues that substantial elements of the Civil Code were drawn from the Civil Law, Feudal Customs, Canon Law, Royal Ordinances, and Laws of the Revolutionary Assemblies, showing how firmly traditional values were entrenched in the new set of laws despite the annihilating processes of the Revolution. According to Ellis (2003), on several points of the code, the legislative reforms of the Revolution were diluted or abandoned. Several other sources stress the bond between some parts of the code (ex. the articles regulating family) and French traditional values. ${ }^{21}$ It is likely then that the similarities between local and French norms that pervaded the new codes facilitated the assimilation of the new set of institutions.

\section{DATA AND VARIABLES}

To investigate how cultural proximity influences the effects of institutional transplants on long-term economic outcomes, we collect and digitize detailed information from historical sources on pre-Napoleonic principalities. We complement this dataset with cross-sectional census data on 447 Prussian counties immediately after German unification (1871) from the Ifo Prussian Economic History Database (iPEHD). ${ }^{22}$ In particular, we map all the counties surveyed in the census into 36 eighteenth-century states, henceforth principalities: this allows us to build pre-Napoleonic, principality- or region-level variables that will serve as measures of cultural and institutional proximity. The list of pre-Napoleonic principalities is reported in the Data Appendix.

Following an established literature (Allen, 2001; Galloway et al., 1994; Becker and Woessmann, 2009), we use wages to proxy for economic performance. Our main measure of county-level income is the average annual wage of male elementary school teachers from the 1886 Education Census. This is the earliest direct

\footnotetext{
${ }^{21}$ Stetson (1987) observes that "[the Civil Code] was not a new set of laws. The family code was based on traditional ideals and customs dominant in France since the thirteenth century". Finally Lobingier (1918) outlines the profiles of the four members of the Commission to draft the Code and writes that "of the four who were selected, everyone was past middle age and a conservative, at heart attached to the old regime, and Napoleon knew it" (pag 117).

${ }^{22}$ For additional information on Prussian census data, see Becker et al., 2014. We chose this period because it guarantees the widest geographical coverage (including the former members of the Confederation of the Rhine) and a sufficiently long time lag for the new institutions to affect economic performance. The difference between our sample and that used in Becker and Woessmann (2009) is that five counties could not be mapped onto pre-Napoleonic principalities. Our results are not affected if we include the observations in the specifications with no pre-Napoleonic controls.
} 
measure of income available for all counties. Teacher salaries, albeit representative of a single occupational group, reflect the development of the county, as its main determinants are local contributions. ${ }^{23}$ One drawback of this proxy is that it may be influenced both by the value that the local community attaches to education and by other benefits provided to teachers (e.g., free housing). In our empirical analysis, we address these issues by controlling for factors that affect both the demand for teachers (e.g., the number of pupils and the demographic structure of the population) and the supply of teachers (e.g., free housing and the total number of teachers). By exploiting later waves of the Prussian census, we assess the robustness of our results using the wages of (unskilled) day laborers in 1892 and income tax revenue per capita, an additional income proxy used by Patrick Galloway et al. (1994) and Sasha Becker and Ludger Woessmann (2009).

Our main measure of institutional transplantation is a binary variable, which takes the value 1 if the county is either in a province annexed by the French Empire (e.g., the Rhineland) or in a satellite state (e.g., the Kingdom of Westphalia). This variable reflects the presence of formal French institutions since, in our sample, all territories under direct or indirect control of Napoleon were subject to the Civil Code and, at least partially, the set of modernizing reforms. ${ }^{24}$ Although exposure to the new institutions was not homogeneous across principalities, we prefer a dichotomous variable as our baseline measure to prevent our results from being driven by the controversial dating of the modernizing reforms (see Kopsidis and Bromley, 2016). However, in Section A we employ alternative proxies for institutions that account for the varying intensity of institutional treatment.

Following the existing literature (e.g., Guiso et al., 2009, Spolaore and Wacziarg, 2009 and Fisman et al., 2017), we use religious affiliation as our main proxy for cultural similarity to France. Religious affiliation synthesizes various cultural aspects beyond the mere spiritual dimension. As previously mentioned, religion was of paramount importance in shaping the politics of the Holy Roman Empire, determining alliances, wars, marriages and lineages. The anecdotal evidence reported below suggests that the reaction to the French rule was different between Catholics and Protestants, and that Catholic territories were closer to the identity of the French authority and to the content of the new set of rules, which were imbued with centuries of French culture. Accordingly, we use the share of Protestants in the county as an inverse proxy for cultural similarity. We draw this information from the 1871 Prussian census. Because religious affiliation is highly persistent across centuries, cross-county variation in this measure is mostly driven by long-run differences in cultural traits, which likely existed prior to the French invasion. ${ }^{25}$

\footnotetext{
${ }^{23}$ For more details, see Becker and Woessmann (2009) and Schleusen (1989).

${ }^{24}$ The only exception in our sample is the Duchy of Nassau, where the Code was formally adopted but never entered into force. In our main specification, we include the few counties of Nassau as satellite states since the Duchy joined the Confederation of the Rhine. We drop the Nassau territories from our sample in a robustness check; see Section A of the appendix.

${ }^{25}$ Cantoni (2015) finds a correlation of 0.98 between the Protestant shares in 1820 and 1900 across Germany. See Cantoni (2012) and Falck et al. (2012) for other examples of papers documenting the persistence
} 
Table 1: Summary Statistics

\begin{tabular}{lccccc}
\hline Variable & Mean & Std. dev. & Min. & Max. & N \\
\hline Napoleon & 0.532 & 0.5 & 0 & 1 & 447 \\
French Empire & 0.116 & 0.321 & 0 & 1 & 447 \\
Satellite States & 0.416 & 0.493 & 0 & 1 & 447 \\
Years of French Invasion & 4.615 & 5.831 & 0 & 19 & 447 \\
Income of Male Elem. School Teachers (1886) & 983.123 & 201.322 & 711.961 & 1954.194 & 447 \\
Protestant Share & 0.644 & 0.377 & 0.003 & 0.999 & 447 \\
\% of County Population in Urban Areas & 0.276 & 0.22 & 0 & 1 & 447 \\
\% Females & 0.51 & 0.015 & 0.44 & 0.546 & 447 \\
\% Age under 10 & 0.247 & 0.025 & 0.153 & 0.299 & 447 \\
Total Population (log) & 10.804 & 0.416 & 9.359 & 13.625 & 447 \\
County Area (log) & 10.798 & 1.152 & 5.313 & 12.955 & 447 \\
University in 1517 & 0.022 & 0.148 & 0 & 1 & 447 \\
Hanseatic or Imperial City & 0.098 & 0.298 & 0 & 1 & 447 \\
Coal Deposits & 0.273 & 0.446 & 0 & 1 & 447 \\
\hline
\end{tabular}

In our analysis, we use a rich set of controls, including historical, geographic and contemporaneous controls. Historical controls are meant to capture pre-existing differences across counties. We construct a dummy variable indicating the presence of Hanseatic or free imperial cities in the sixteenth century, since they benefited from particular economic and diplomatic privileges. We also control for pre-Napoleonic economic development using the urban population in 1500 from Becker and Woessmann (2009). Geographic controls include the latitude (in radians), the log of total area of the county and a dummy variable for Polishspeaking provinces (which are mainly located in the east and underdeveloped). ${ }^{26}$ In addition, we always include a dummy variable to control for counties with coal deposits since access to natural resources could affect western German industrialization and differential regional development. ${ }^{27}$ Following Alexander Donges et al. (2017), we collect the location of the deposits from map BI (coal mining) in Ernst Pfohl and Ernst Friedrich (1928). Using information from the 1871 and 1886 censuses, we control for the demographic and social characteristics of the population and the industrial features of the county, as well as other aspects that may affect the wages of teachers (Socioeconomic and Education Controls). ${ }^{28}$ Table 1 reports summary

of denominational affiliation. In Section A of the appendix, we address potential endogeneity concerns by using four alternative Protestant measures: (i) a dummy variable indicating Protestant majority (ii) the share of Protestants in the aftermath of the Congress of Vienna, which is available for a subsample of 349 counties; (iii) a dummy variable indicating the religious affiliation of the principality at the beginning of the seventeenth century; and (iv) the 1871 Protestant share instrumented with the distance from Wittemberg.

${ }^{26}$ We do not include longitude in our specifications because it is strongly correlated with the institutional variable. Indeed, the Napoleonic invasion followed a west-east trajectory starting from neighboring territories and moving toward Russia. This renders longitude a proxy for the intensity of French presence. In Section A of the appendix, we carefully address this issue by conditioning on different sets of fixed effects.

${ }^{27}$ Fernihough and O'Rourke (2014) provide an analysis on the impact of coal deposits on economic development during the industrial revolution.

${ }^{28}$ Specifically, Socioeconomic Controls include the log of total population size, the percentage of the county population in urban areas in 1871, the percentage of Jews, the percentage of the labor force in mining in 1882 , the number of farms in 1882, the log of the distance from the imperial capital (Berlin) and from the 
statistics for our main variables. ${ }^{29}$ The table shows that approximately one-half of the sample was under the direct $(11.6 \%)$ or indirect $(41.6 \%)$ control of Napoleon. Moreover, we observe significant variability in the annual wages of male elementary school teachers, which range from 712 to 1954 gold marks. Table 1 also reveals quite a high variability in the linguistic distance measure. Moreover, while eighteenth-century Prussia was mainly Protestant (the average Protestant share is $64.4 \%$ ), we observe sizable differences in counties' religious affiliation.

\section{EMPIRICAL STRATEGY}

This section presents the empirical model we use to test our central hypothesis, namely, that institutional transfer was more effective - and hence induced better economic performance - in places that were more culturally similar to France.

Our baseline specification is as follows:

$$
\begin{aligned}
y_{i}= & \alpha+\beta_{1} \text { Cultural dist }_{i}+\beta_{2} \text { Napoleon }_{i}+\beta_{3} \text { Cultural dist }_{i} \times \text { Napoleon }_{i} \\
& +\mathbf{H}_{i} \beta_{4}+\mathbf{G}_{i} \beta_{5}+\mathbf{E}_{i} \beta_{6}+\mathbf{X}_{i} \beta_{7}+\mathbf{H}_{i} \times \text { Napoleon }_{i} \beta_{8}+\mathbf{G}_{i} \times \text { Napoleon }_{i} \beta_{9}+\varepsilon_{i}
\end{aligned}
$$

where $y_{i}$ is the log of the average income of male elementary school teachers in county $i$; Cultural dist $t_{i}$ is one of our measures of cultural distance; Napoleon $i$ is a binary variable indicating French influence; $\mathbf{H}_{\mathbf{i}}$, $\mathbf{G}_{\mathbf{i}}, \mathbf{E}_{\mathbf{i}}$ and $\mathbf{X}_{\mathbf{i}}$ are vectors of historical, geographical, educational and socioeconomic controls, respectively; and $\varepsilon_{i}$ is an error term. Throughout the paper, all standard errors are robust to allow for heteroskedasticity in the variance-covariance matrix. ${ }^{30}$ To account for the differential effects of the institutions depending on pre-existing characteristics that are not related to culture, the specification also includes interactions between the institutional dummy, Napoleon ${ }_{i}$, and pre-Napoleonic and geographic variables. We interact only controls that were already determined at the time of the Napoleonic invasion.

Our aim is to identify the differential impacts of French institutions on economic outcomes across levels of cultural similarity. The coefficient of interest is therefore $\beta_{3}$, which captures the differential effects of institutions on economic outcomes across counties with different degrees of cultural proximity to France.

The identification of $\beta_{3}$ requires that other characteristics correlated with prosperity did not influence

district capital, and the year of annexation by Prussia. Education Controls include the percentage of pupils traveling a distance of over $3 \mathrm{~km}$ to attend school, the log of the total number of pupils in 1886, the $\log$ of the total number of teachers in 1886 and the number of free apartments for male teachers in 1886.

${ }^{29}$ Summary statistics, divided by treatment and control group, are reported in Table A1 in the Appendix.

${ }^{30}$ In the robustness checks, section A of appendix A, we cluster the standard error at the pre-Napoleonic principality, post-Napoleonic kingdom, and 1871 Prussian district to allow for an arbitrary variancecovariance matrix capturing potential serial correlation in the residual error term. 
Napoleon's invasion across areas with different degrees of cultural proximity to France. As previously discussed, the French invasions had primarily geopolitical, military and ideological motives. Anecdotal evidence reported by Donges et al. (2017) shows how occupied regions, like Rhineland-Westphalia, were not economically more promising ex ante than those not invaded, like Saxony. This makes it unlikely that Napoleon systematically selected territories based on their cultural traits, cherry-picking rich culturally close regions and poor culturally distant ones. ${ }^{31}$

Table 2: Exogeneity Test - Napoleonic Invasion and Protestant Share

\begin{tabular}{|c|c|c|c|c|c|c|}
\hline Dependent Variable & $\begin{array}{l}\text { \% Urban Pop } \\
\% 1500 \\
\text { (1) }\end{array}$ & $\begin{array}{c}\text { \% Urban Rate } \\
\% 1790 \\
\text { (2) }\end{array}$ & $\begin{array}{l}\text { Pop. Density } \\
1790 \\
\text { (3) }\end{array}$ & $\begin{array}{l}\text { Hansea./Imper. } \\
\text { city } \\
\text { (4) }\end{array}$ & $\begin{array}{c}\text { Educational } \\
\text { Centers } \\
\text { (5) }\end{array}$ & $\begin{array}{l}\text { Coal } \\
\text { Deposits } \\
\text { (6) }\end{array}$ \\
\hline Napoleon & $\begin{array}{l}31.27^{* *} \\
(13.70)\end{array}$ & $\begin{array}{c}-0.659 \\
(1.114)\end{array}$ & $\begin{array}{l}-207.5 \\
(129.6)\end{array}$ & $\begin{array}{l}-3.820 \\
(2.430)\end{array}$ & $\begin{array}{c}1.100 \\
(1.562)\end{array}$ & $\begin{array}{c}-4.924^{* *} \\
(2.200)\end{array}$ \\
\hline Prot. Share & $\begin{array}{c}-3.439^{* *} \\
(1.471)\end{array}$ & $\begin{array}{c}-0.0174 \\
(0.0364)\end{array}$ & $\begin{array}{l}-8.600 \\
(6.021)\end{array}$ & $\begin{array}{c}-0.0788 \\
(0.0866)\end{array}$ & $\begin{array}{c}0.0198 \\
(0.0193)\end{array}$ & $\begin{array}{c}0.102 \\
(0.101)\end{array}$ \\
\hline Nap. $\times$ Prot. Share & $\begin{array}{l}-1.813 \\
(1.820)\end{array}$ & $\begin{array}{c}0.0610 \\
(0.0569)\end{array}$ & $\begin{array}{c}6.593 \\
(7.098)\end{array}$ & $\begin{array}{l}0.0940 \\
(0.132)\end{array}$ & $\begin{array}{c}-0.0940 \\
(0.0901)\end{array}$ & $\begin{array}{l}-0.0597 \\
(0.157)\end{array}$ \\
\hline$R^{2}$ & & 0 & 0.4 & 0 & 0.2 & 0.157 \\
\hline Obs. & 447 & 413 & 414 & 447 & 447 & 447 \\
\hline
\end{tabular}

Notes: The dependent variable is in the column heading. Poisson regressions in column (1). All specifications include Geographic Controls, Historical Controls (when not in the dependent variable), distance from the imperial capital (Berlin), distance from the district capital, Hist \& Geo Interactions and the interactions of distance from the imperial capital (Berlin) and distance from the district capital with the dummy Napoleon. See also the notes to Table 3. Robust standard errors in parentheses. ${ }^{* * *} \mathrm{p}<0.01,{ }^{* *} \mathrm{p}<0.05,{ }^{*} \mathrm{p}<0.1$

We test the exogeneity assumption with a battery of regressions estimating our baseline specification using as dependent variables the pre-Napoleonic variables available in our dataset. Significant coefficients on the Napoleon $\times$ Prot. Share may be symptomatic of the presence of pre-existing characteristics that simultaneously influence culture, institutions and economic performance. The results are reported in Table 2. In column (1), we implement the baseline specification using the urbanization rate in $1500,{ }^{32}$. In columns (2)-(3), we use urbanization rate and population density in 1790 as the dependent variable, respectively. We have constructed these measures by exploiting the HYDE database and summing the grid-level information on population and urbanization in our county-level data. In column (4), we run a linear probability model using the dummy variable capturing the presence of Hanseatic and Free Imperial Cities, while in column (5), we use a dummy that indicates the presence of educational centers, either universities in the Holy Roman Empire or the presence of primary educational centers (schools and monasteries), in 1517.

\footnotetext{
${ }^{31}$ In the Appendix, we provide empirical support for this statement by testing whether we can predict either the probability of falling under French influence or the duration of the French rule with pre-1789 variables that account for geographic and economic characteristics, such as city population or coal deposits. The results reported in Table A2 reveal no systematic correlation between Napoleonic invasion and all available proxies for economic development prior to the French invasion.

${ }^{32}$ To address the high number of zeros ( $84 \%$ of the observations), we estimate a Poisson regression in column (1).
} 
Finally, in column (6), we exploit a dummy variable capturing the presence of coal deposits. The results show that the coefficients on the interaction term Napoleon $\times$ Prot. Share are never significant. These findings can be interpreted as evidence that pre-Napoleonic observables are balanced both across treatment and across cultural distance, which supports our identification assumption.

\section{RESULTS}

\section{Baseline Estimates}

This section reports the results of our baseline analysis. Column (1) of Table 3 shows the estimates of a specification that includes only the institutional dummy, Napoleon, the cultural distance measure, Prot. Share, and geographical controls. In the following columns, we progressively enrich the specification until we estimate our baseline model in column (5). Column (2) introduces the interaction term Napoleon $\times$ Prot. Share, while column (3) adds historical variables that take into account counties' pre-Napoleonic observable differences. Column (4) adds socioeconomic and education controls. These variables not only capture the economic and social outlook of the county after the Congress of Vienna but also are meant to account for elements that influence the demand for and/or supply of teachers, thereby directly affecting our preferred proxy for economic performance. Unlike previous controls, these can be considered "bad" controls (Angrist and Pischke, 2009) since they are themselves potential outcomes of institutional transplants. However, our results are robust, and neither the magnitudes nor the statistical significance of our coefficients of interest are extremely affected. Finally, to eliminate the possibility that the estimate of our coefficient of interest is spuriously driven by the interplay of transplanted institutions with pre-existing county-level characteristics, column (5) implements our baseline model and includes interactions between Napoleonic institutions and historical and geographic controls, thereby obtaining our baseline model. Table A3 in the appendix reports all the coefficients of this specification, while table A8 in the appendix repeats the analysis on the subsample of invaded territories.

Consistent with the existing literature, the linear effects of good institutions (Napoleon) on our measure of economic performance is positive and statistically significant across all specifications, suggesting that transplanting progressive institutions can indeed improve economic outcomes. ${ }^{33}$ Moreover, Protestant affiliation (Protestant Share) is always positively associated with better economic outcomes, consistent with

\footnotetext{
${ }^{33}$ In column (5), we do not report the coefficient associated with the linear term Napoleon, as it can no longer be interpreted as the linear effect of good institutions because, in that specification, we include all interactions between historical and geographical controls and the Napoleon dummy. The effect of Napoleon is approximately 0.04 , significant at a $10 \%$ level, when we evaluate it at the average value of the continuous variables when all dummies equal zero, while it is not statistically different from zero when all the dummies equal one.
} 
Table 3: Institutions and Religious Affiliation

\begin{tabular}{lccccc}
\hline $\begin{array}{l}\text { Log Average Wage for } \\
\text { Male Elementary Teachers in 1886 }\end{array}$ & $(1)$ & $(2)$ & $(3)$ & $(4)$ & $(5)$ \\
\hline Napoleon & $0.0377^{* *}$ & $0.114^{* * *}$ & $0.109^{* * *}$ & $0.121^{* * * *}$ & \\
& $(0.0172)$ & $(0.0224)$ & $(0.0220)$ & $(0.0278)$ & \\
Protestant Share & $0.0938^{* * *}$ & $0.172^{* * *}$ & $0.184^{* * *}$ & $0.170^{* * *}$ & $0.190^{* * *}$ \\
& $(0.0189)$ & $(0.0261)$ & $(0.0254)$ & $(0.0330)$ & $(0.0401)$ \\
Napoleon $\times$ Protestant Share & & $-0.112^{* * *}$ & $-0.121^{* * *}$ & $-0.174^{* * *}$ & $-0.208^{* * *}$ \\
& & $(0.0332)$ & $(0.0325)$ & $(0.0335)$ & $(0.0403)$ \\
\hline Geographic Controls & yes & yes & yes & yes & yes \\
Historical Controls & no & no & yes & yes & yes \\
Socioeconomic Controls & no & no & no & yes & yes \\
Education Controls & no & no & no & yes & yes \\
Hist \& Geo Interactions & no & no & no & no & yes \\
$R^{2}$ & 0.396 & 0.406 & 0.429 & 0.667 & 0.677 \\
Obs. & 447 & 447 & 447 & 447 & 447 \\
\hline
\end{tabular}

Notes: The dependent variable is the logarithm of the average annual wage of an elementary school teacher in 1886. Napoleon is a dummy variable indicating the presence of French institutions. Protestant Share is measured in 1871. Geographic Controls: latitude, area of the county (log) and dummy variables for Polish-speaking areas and coal deposits. Historical Controls: population in 1500 and Hanseatic or Imperial cities. Socioeconomic Controls: total population size $(\log )$, percentage of county population in urban areas in 1871, percentage of Jews, percentage of labor force in mining in 1882, number of farms in $1882(\mathrm{log})$, distance from the imperial capital (Berlin), distance from the district capital and year of annexation by Prussia. Education Controls: percentage of pupils traveling over $3 \mathrm{~km}$ to school, total number of pupils in 1886 $(\log )$, total number of teachers in $1886(\log )$, and number of free apartments for male teachers in 1886. Hist \& Geo Interactions: interaction between Napoleon and both Geographic Controls and Historical Controls. Robust standard errors in parentheses.

${ }^{* * *} \mathrm{p}<0.01,{ }^{* *} \mathrm{p}<0.05,{ }^{*} \mathrm{p}<0.1$

\section{Figure 1: Predicted Effect of Napoleonic Institutions}

Becker and Woessmann (2009). Notably, our coefficient of interest $\left(\beta_{3}\right)$ is always negative, significant, and remarkably stable across specifications, indicating that Napoleonic institutions had virtually no impact on economic performance in culturally distant areas. To be more precise, the positive effect of institutions vanishes for a county whose Protestant share of the population equals $70 \%$ (the average Protestant share is $64 \%$ ). This result is also illustrated in Figure 1 which contrasts the predicted values of the income measure at different levels of the Protestant share for counties that did and did not receive the Napoleonic institutions. Furthermore, the magnitude of $\beta_{3}$ suggests that the moderating effect of cultural distance is sizable. Indeed, in counties that receive the French institutions, a one-standard-deviation increase in the Protestant share corresponds to a reduction in the county income of approximately $8 \%$. Comparatively, the presence of a coal deposit in a county invaded by Napoleon increases the local income by approximately $6 \%$.

In Table A4 in appendix A, we perform an extensive sensitivity analysis addressing possible measure- 
ment and specification issues. First, we show that the results are robust to the use of alternative measures of economic prosperity. In particular, we estimate our main specification using average income of male elementary school teachers in levels, log wage of a daily laborer in 1892, income tax revenue per capita and urban population in 1871. Second, we use alternative measures of religious affiliation. Specifically, we use a dummy variable capturing Protestant (absolute) majority, Protestant share in the first available wave of the Prussian census (1816), a historical measure of the Protestant majority in the seventeenth century and the distance from Wittenberg (IV specification). Third, we introduce additional controls that may affect our results. Specifically, we introduce population densities and urbanization in 1790, a county-level price index, measures for locally born population, literacy rate, educational quality measures and a dummy variable capturing the presence of ore deposits. To allow for potential correlation in the error term, we cluster standard errors at pre-Napoleonic-principality level, at the pre-Napoleonic-ruler level, at the preunitarystate level after the Napoleonic German mediatization and at the Prussian political district level in 1871. Then, we show that our evidence is not driven by influential observations. We trim and winsorize the extreme $1 \%$ of observations of our dependent variable and consider alternative subsamples. The results of all these different specifications show that the association between French institutions and religious affiliation is always statistically significant, negative and remarkably stable.

In Table A5 in appendix A, we repeat the analysis conditioning on different sets of fixed effects to address the concern that the presence of unobserved characteristics may influence both economic outcomes and cultural traits. Specifically, we add to the baseline specification ruler fixed effects, and three groups of geographic dummies (i.e., dummies for quintiles of distance from Berlin, Paris and the French border). The results are confirmed even when exploiting for identification only within region variation.

Table A6 in appendix A investigates how the moderating effect of cultural distance changes with the length of exposure to the new institutions. We use three measures that capture different facets of the intensity of the institutional treatment: (i) dummy variables that distinguish between territories that were annexed by the French Empire and those belonging to the Confederation of the Rhine (i.e., satellite states) (ii) the number of years of French influence (iii) an index proposed by Acemoglu et al. (2011) that summarizes different reforms. We find that cultural distance plays a significant role even when the intensity of the institutional treatment increases.

Finally, Table A7 in appendix A reports the results of different specifications testing alternative explanations for our findings. We focus on factors, other than culture, that may interact with the new institutions, thereby affecting long-run economic outcomes. In particular, we analyze the impact of (i) state capacity, (ii) institutional proximity, (iii) legitimacy of the pre-Napoleonic ruler, (iv) education policies, (v) previous French invasions, (vi) severity of the Napoleonic conflict, and (vii) religious and linguistic fragmentation. Our results are not affected by the inclusion of this additional set of variables confirming 
that despite complex interactions among institutions and historical and socioeconomic factors, cultural similarity does play a role in institutional transplants and long-term economic outcomes.

\section{Difference-in-Differences Specification}

Our second strategy is to test our hypothesis using a different dataset, which allows us to implement a difference-in-differences (DID) specification. We use the data compiled by Acemoglu et al. (2011), which contain information on urbanization and religious affiliation for a panel of 19 independent German states (or provinces of larger states) for the years 1750, 1800, 1850, 1875 and 1900. Even though these data are available at a higher level of aggregation (19 states vs. more than 440 counties), they allow us to test our hypothesis using within-region variation over time. Accordingly, our baseline DID specification reads as follows:

$$
\begin{aligned}
\text { urb_rate }_{i t}= & \alpha_{1} \text { Post }_{t}+\alpha_{2} \text { Post }_{t} \times \text { Napoleon }_{i}+\alpha_{3} \text { Post }_{t} \times \text { Prot }_{i} \\
& +\alpha_{4} \text { Post }_{t} \times \text { Napoleon }_{i} \times \text { Prot }_{i}+\mu_{i}+\varepsilon_{i t}
\end{aligned}
$$

where $u r b_{-} r a t e_{i t}$ is the urbanization rate of state $i$ in year $t$ (the proxy for economic outcomes in this dataset), Post is a dummy variable that equals one in the years after the Napoleonic invasion (i.e., in the second half of the nineteenth century), Napoleon is a time-invariant dummy variable that captures the French presence (treatment) in the state, Prot is the share of Protestants around 1800 (constant over time), and $\mu_{i}$ are state fixed effects.

As already mentioned, to avoid distortions due to errors in the recording of the timing of the reforms, we prefer to use a dummy variable capturing the presence of French rule rather than the reform index, proposed by Acemoglu et al. (2011), based on the duration of each reform. Moreover, using a dummy variable that indicates French presence allows us to reduce concerns about potential endogeneity in the duration and the intensity of French reforms. Indeed, whether a state retains the set of reforms after the Congress of Vienna is a choice variable that may well depend on the success of the institutional transplant itself.

The results are reported in Table 4. Column (1) shows the baseline DID estimates. The coefficient on the Post dummy indicates that German areas grew in the second half of the nineteenth century. The positive coefficient on Napoleon $\times$ Post suggests that growth was higher in places that received French institutions. The negative coefficient on the interaction between French institutions and Protestant share after institutional transplant confirms that the positive effect of French reforms was not homogeneous across different levels of cultural proximity. Indeed, the estimates suggest that the positive effect of good institutions vanishes for a share of Protestants of approximately 85\% (the median Protestant share in this 
sample is $80 \%$ ). In column (2), we show that the results are robust to weighting the regression by total population in 1750, as in Acemoglu et al. (2011). In column (3), we reach the same conclusion using a different measure of French institutions, i.e., the number of years of French presence. Finally, in column (4), we replace the Post indicator with a full set of year dummies (we take 1800 as the reference year). The positive average effect of the Napoleonic reform appears only in the long term (around 1875, i.e., 60 years after the Congress of Vienna) and, perhaps more interestingly, only in states characterized by a Catholic majority. ${ }^{34}$

Using a different dataset and a different empirical strategy, the results of this section confirm that cultural distance from France played a role in the success of the institutional transplantation process. However, we find that the positive effect of radical reforms unfolds only in the long term and only in places that were more amenable to the French reforms. We discuss two possible explanations for the existence of a time lag between the imposition of the institutions and the emergence of their positive economic effect even in culturally close territories: i) the negative heritage of the military conflicts and the effect of French foreign policies and ii) the gradual interaction of the Prussian policies with French heritage.

Obviously, the arrival of the French army placed heavy burdens upon local communities: their villages were invaded, and their towns and cities were besieged and occupied. French soldiers often supported themselves through requisitions and plundering, but the forces of the German states also often required local inhabitants to provide them with supplies and transport. The stationing of troops also brought with it both diseases that often spread to livestock and inflationary pressures especially on the prices of foodstuff (Leighton, 2013). Moreover, war had left counties with high debts and reconstruction burdens. However, perhaps the highest toll was payed in terms of human capital depletion. The total war dead among all the European armies during the Napoleonic campaign was estimated to be approximately 3 million, with additional civilian losses of nearly 1 million, mainly concentrated among young men. In addition to immediately depriving the productive sectors of a labor force, the loss of so many men upset the population balance between the sexes and had long-term consequences on population growth. Finally, in non-annexed territories, the manufacturing sector was damaged by French protectionist policies that deprived the sector from cheap imports from Britain and at the same time made it hard to export to France. In addition, capital was inadequate to create new enterprises to compensate for the lack of British manufactured goods. Coastal cities and their merchants were heavily affected, and industries related to naval trade, such as ship-

\footnotetext{
${ }^{34}$ The significant and positive coefficient on the interaction Napoleon $\times$ Prot.Share $\times 1750$ is driven by the Landgraviate of Hesse-Kassel, the Duchy of Brunswick-Wolfenbüttel and Electorate of Hanover. All these territories are coded as invaded by Napoleon, have a high share of Protestants (greater than 80\%) and experience a drop in the urbanization growth rate between 1750 and 1800. The Landgraviate of HesseKassel and the Duchy of Brunswick-Wolfenbüttel register a negative growth in the urbanization rate only in between 1750 an 1800 while, in the same years, the Electorate of Hanover halves its growth rate compared to the previous 50 years, an unusual slowdown in comparison to the high growth rates experienced by the territory. This anomalous drop in the urbanization growth rate is most probably due to the participation of these three principalities in the seven-year war.
} 
building and rope-making, declined, as did many other industries that relied on overseas markets, such as the linen industries. All in all, the Napoleonic wars left central Europe severely battered, and the positive heritage of progressive reforms took time to manifest itself.

After the congress of Vienna, Prussia experienced a periphery-center conflict characterized by tension between western reformers and Berlin conservatives, which slowed the reform process. It was not until the 1840s that the heritage of the French institutions could interact with Prussian virtuous reforms, favoring the Prussian industrial take off. For example, in the aftermath of Napoleon's downfall, Rhenish infant industries - deeply integrated into Napoleon's Continental System - suffered greatly both from the imposition of Dutch and French tariffs and from international competition with Britain. The progressive creation of the German customs union benefited Rhenish industry by facilitating the formation of a German-wide national market for goods and especially by fostering East-West commerce, increasing fiscal efficiency and providing both mild protection of nascent industry and the access to duty free raw materials. ${ }^{35}$ Furthermore, the 1840 s witnessed a turn to a more favorable governmental attitude toward industrial development, which is well illustrated by the new policies that boosted railroad building, monetary integration and the reform of the banking system (Tilly, 1966). All these institutional changes spurred private investments in productive industrial activities, allowing for a boost in the industrialization process.

\footnotetext{
${ }^{35}$ For an in-depth analysis of the effect of Prussian trade policies, see Pierenkemper and Tilly (2004) chapter 3.
} 
Table 4: Difference-in-Differences Estimation

\begin{tabular}{|c|c|c|c|c|}
\hline Urbanization Rate & $\begin{array}{c}\text { Baseline } \\
\text { (1) }\end{array}$ & $\begin{array}{c}\text { Weighted } \\
\text { (2) }\end{array}$ & $\begin{array}{l}\text { Years of } \\
\text { French } \\
\text { (3) }\end{array}$ & $\begin{array}{c}\text { Napoleon } \\
\times \text { Years } \\
(4)\end{array}$ \\
\hline Post & $\begin{array}{c}9.925^{* * *} \\
(2.442)\end{array}$ & $\begin{array}{c}10.38^{* * *} \\
(2.325)\end{array}$ & $\begin{array}{c}11.64^{* * *} \\
(2.949)\end{array}$ & \\
\hline Napoleon $\times$ Post & $\begin{array}{c}21.78^{* * *} \\
(7.467)\end{array}$ & $\begin{array}{c}21.23^{* * *} \\
(4.889)\end{array}$ & $\begin{array}{c}23.29^{* * *} \\
(6.842)\end{array}$ & \\
\hline Post $\times$ Nap. $\times$ Prot. Share & $\begin{array}{c}-28.13^{* * *} \\
(8.458)\end{array}$ & $\begin{array}{c}-29.18^{* * *} \\
(6.563)\end{array}$ & & \\
\hline Years of French $\times$ Post & & & $\begin{array}{c}1.454^{* * *} \\
(0.272)\end{array}$ & \\
\hline Post $\times$ French Yrs. $\times$ Prot. Share & & & $\begin{array}{c}-2.233^{* * *} \\
(0.751)\end{array}$ & \\
\hline Napoleon $\times 1700$ & & & & $\begin{array}{l}-20.68 \\
(14.45)\end{array}$ \\
\hline Napoleon $\times 1750$ & & & & $\begin{array}{c}-10.19^{* *} \\
(3.956)\end{array}$ \\
\hline Napoleon $\times 1850$ & & & & $\begin{array}{l}-1.302 \\
(4.450)\end{array}$ \\
\hline Napoleon $\times 1875$ & & & & $\begin{array}{l}16.99 * \\
(8.506)\end{array}$ \\
\hline Napoleon $\times 1900$ & & & & $\begin{array}{c}30.24^{* * *} \\
(9.896)\end{array}$ \\
\hline Prot. Share $\times$ Nap. $\times 1700$ & & & & $\begin{array}{c}24.65 \\
(16.57)\end{array}$ \\
\hline Prot. Share $\times$ Nap. $\times 1750$ & & & & $\begin{array}{l}12.20^{* *} \\
(4.642)\end{array}$ \\
\hline Prot. Share $\times$ Nap. $\times 1850$ & & & & $\begin{array}{c}0.00186 \\
(5.497)\end{array}$ \\
\hline Prot. Share $\times$ Nap. $\times 1875$ & & & & $\begin{array}{c}-23.15^{* *} \\
(10.47)\end{array}$ \\
\hline Prot. Share $\times$ Nap. $\times 1900$ & & & & $\begin{array}{c}-37.89^{* * *} \\
(11.70)\end{array}$ \\
\hline Number of id & 19 & 19 & 19 & 19 \\
\hline$R^{2}$ & 0.506 & 0.530 & 0.503 & 0.878 \\
\hline Obs. & 109 & 109 & 109 & 109 \\
\hline
\end{tabular}

Notes: The dependent variable is the urbanization rate of the German territories. All regressions have territory fixed effects that subsume the linear effects of Napoleon, Prot. Share and Napoleon $\times$ Prot. Share (all of which are constant over time). Column (4) includes year fixed effects. The reference year is 1800. All specifications include interactions between post (or year) and the Protestant share. The results are not reported for the sake of readability. Regressions are weighted by territories' total population in 1750. Robust standard errors are clustered by territory. $\quad{ }^{* * *} \mathrm{p}<0.01,{ }^{* *} \mathrm{p}<0.05,{ }^{*} \mathrm{p}<0.1$

Notes: Marginal effect of Napoleonic institutions predicted at different levels of Protestant share. All other variables are considered at their sample mean 
Our results suggest that the positive effect of German reforms, which took off only in the second half of the nineteenth century, interacted with Napoleonic institutions and that this fruitful interaction was relatively stronger in the culturally closer territories.

\section{Additional cultural dimensions}

Religious affiliation captures persistent cultural similarities across counties but there might be other important cultural aspects that interact with the adoption of transplanted institutions. In this section, we study distinct aspects of cultural similarities occurring either among members of the lower class or among the elites. As a proxy for cultural distance among lower class members we use linguistic distance, while to measure cultural distance among elites we build a variable based on the affinity between the eighteenthcentury rulers and French culture. ${ }^{36}$ The results are reported in Table 5 using the same specification as in column (5) of Table 3.

We begin by discussing linguistic distance. Consistent with the existing literature, we interpret language as a reflection of persistent cultural traits (Galor et al., 2017 and Falck et al., 2012) and as a vehicle of social interaction and social influence (Spolaore and Wacziarg (2016) and Spolaore and Wacziarg (2014)). Hence, linguistic distance is likely to serve as an inverse proxy for the diffusion of social norms. We exploit linguistic heterogeneity within Prussia to build a measure of linguistic distance between French and the languages spoken in each county. To this purpose, we leverage the linguistic information reported in the Ethnologue database, which describes the languages that are currently spoken in each NUTS2 region. ${ }^{37}$ As shown in column (1) of Table 5 , the coefficient of interest, $\beta_{3}$, is negative and precisely estimated, and its magnitude suggests that the moderating effect of cultural distance is sizable. Indeed, in counties that received the French institutions, a one-standard-deviation increase in the measure of linguistic distance from the French language (approximately an increase of 2 nodes in the linguistic distance) corresponds to a reduction in the county income of approximately $8 \%$, an effect that is remarkably similar to our estimated baseline effect. Then, to prevent our results from being driven by minor differences in the linguistic distance variable, we use counties' ranking in terms of the linguistic distance. The results are reported in column (2), and they are consistent with the baseline result. Since the Ethnologue database reports currently spoken languages, a possible concern is that linguistic areas may have been affected by the Napoleonic treatment (for example, through migrations). To ensure that our results are not exclusively driven by the assignment of counties to modern linguistic regions, we redefine the linguistic regions exploiting the in-

\footnotetext{
${ }^{36}$ Importantly, the correlation among our proxies of cultural distance - Protestant Share, Linguistic Distance and No French Ties - is positive but not extremely high (the highest correlation is between Linguistic Distance and No French Ties and equals 0.20), suggesting that the three measures capture, at least in part, different facets of cultural similarity.

${ }^{37} \mathrm{~A}$ detailed description of the construction of the linguistic variables is reported in Appendix B.
} 
formation contained in an ancestral language map. ${ }^{38}$ Column (3) shows that the results are unaffected by this sensitivity test.

The second set of alternative cultural distance measures relies on the existence of different attitudes of eighteenth-century rulers toward both Enlightenment ideals and French culture. Indeed, the degree of acceptance of a foreign institution may crucially hinge on the mediation of the ruling class, whose inclinations and attitudes toward the new rules could facilitate their implementation. Using essays, biographies and books, we investigate whether local rulers during the period 1701-1790 (i) had a direct French relative (mother, father, spouse) and, thus, an explicit link to the French aristocracy; (ii) displayed a positive disposition toward the customs and traditions of the French court, ${ }^{39}$ (iii) embraced French Enlightenment ideals; ${ }^{40}$ or (iv) had a long-standing relationship with the French Royal House. ${ }^{41}$ Our first proxy of cultural distance, No French Ties, is a dummy that equals 1 if none of the above conditions is satisfied. ${ }^{42}$ The results are reported in column (4), and the estimated impact of No French Ties is considerably large. This pronounced impact is not surprising because having a dummy that equals one means that no ruler in the century before the Napoleonic invasions had any ties with France, indicating a significant lack of exposure to French culture that translates into a $36 \%$ decrease in the average income of the county in the invaded territories.

Then, to obtain a more precise measure of the potential exposure to French culture through the ruler's attitude, we weight our dummy by the fraction of years a ruler was in power during the period 1701-1790 (column 5). For example, if a ruler with no French ties was in power for 46 years, his or her contribution to our index is 0.51 (i.e., 46 over 90 years). Finally, to alleviate the concern that the variable is distorted by the availability of historical information (as it is likely that large principalities and active rulers are more covered), we redefine the measure to reflect only objective historical exposure to French culture. Specifically, in addition to information on rulers' kinship relations with the French aristocracy, we exploit the presence of Huguenot migrants during the seventeenth century using county-level data collected by Erik Hornung (2014) and complemented by Reginald Lane Poole (1880). It is likely that fruitful interaction with elites and local populations generated a favorable image of these Frenchmen and a positive inclination toward French culture.

\footnotetext{
${ }^{38} \mathrm{As}$ in Spolaore and Wacziarg (2014), the source for the language data is the map provided at http://www.muturzikin.com/carteeurope.htm. The map includes only native languages and discards languages spoken by migrants.

${ }^{39}$ For instance, the Landgrave of Hesse-Kassel, Frederick II, was strongly attracted to French culture and art. During his reign, French influence could be detected not only in architecture, opera and theater performances but also in the choice of French as the language of his inner administration and the local elites.

${ }^{40}$ For instance, the Elector Palatine, Charles Theodore, had assiduous correspondence with Voltaire.

${ }^{41}$ For instance, William Henry, Prince of Nassau-Saarbrucken, often traveled to Paris, where he even received military honors.

${ }^{42}$ Appendix B reports this variable for all the principalities in our sample.
} 
Table 5: Alternative Cultural Measures

\begin{tabular}{|c|c|c|c|c|c|c|}
\hline \multirow[b]{2}{*}{$\begin{array}{l}\text { Log Average Wage for } \\
\text { Male Elementary Teachers in } 1886\end{array}$} & \multicolumn{3}{|c|}{ Linguistic Distance Proxies } & \multicolumn{3}{|c|}{ French Exposure Proxies } \\
\hline & (1) & (2) & (3) & (4) & (5) & (6) \\
\hline Ling. Dist. & $\begin{array}{l}0.0110^{* *} \\
(0.00512)\end{array}$ & & & & & \\
\hline Nap. $\times$ Ling. Dist. & $\begin{array}{l}-0.0132^{* *} \\
(0.00516)\end{array}$ & & & & & \\
\hline Ling. Dist. Rank. & & $\begin{array}{l}0.00017^{* *} \\
(8.28 \mathrm{e}-05)\end{array}$ & & & & \\
\hline Nap. $\times$ Rank. & & $\begin{array}{l}-0.00055^{* * *} \\
(0.00012)\end{array}$ & & & & \\
\hline Ancient Ling. Dist. & & & $\begin{array}{l}0.191^{* *} \\
(0.0815)\end{array}$ & & & \\
\hline Nap. $\times$ Anci. Ling. Dist. & & & $\begin{array}{l}-0.201^{* *} \\
(0.0812)\end{array}$ & & & \\
\hline No French Ties & & & & $\begin{array}{l}0.311^{* * *} \\
(0.0396)\end{array}$ & & \\
\hline Napoleon $\times$ No French Ties & & & & $\begin{array}{l}-0.361^{* * *} \\
(0.0402)\end{array}$ & & \\
\hline No Ties ind. & & & & & $\begin{array}{l}0.362^{* * *} \\
(0.0782)\end{array}$ & \\
\hline Napoleon $\times$ No Ties ind & & & & & $\begin{array}{l}-0.523^{* * *} \\
(0.0832)\end{array}$ & \\
\hline French Exposure & & & & & & $\begin{array}{r}-0.00983 \\
(0.0216)\end{array}$ \\
\hline Nap. $\times$ Fr. Exposure & & & & & & $\begin{array}{l}0.0703^{* *} \\
(0.0314)\end{array}$ \\
\hline$R^{2}$ & 0.658 & 0.668 & 0.660 & 0.727 & 0.687 & 0.659 \\
\hline Obs. & 447 & 447 & 447 & 447 & 426 & 447 \\
\hline
\end{tabular}

Notes: The column headings indicate the cultural-distance-proxy groups used in the specification.The dependent variable is the logarithm of the average annual wage of an elementary school teacher in 1886 . The specifications include Geographic Controls, Historical Controls, Socioeconomic Controls, Education Controls and the interactions between the new measure of institutional intensity with historical and geographical controls. See also the notes to Table 3. Robust standard errors in parentheses.

${ }^{* * *} \mathrm{p}<0.01,{ }^{* *} \mathrm{p}<0.05,{ }^{*} \mathrm{p}<0.1$ 
We then construct a dummy variable, French Exposure, that equals one if local rulers during the period 1701-1790 had a direct French relative (mother, father, spouse) or if the county registered the presence of Huguenot colonies. The results in column (6) show that transplants were more effective if the local population had previous exposure to French culture.

In this section, we highlight different cultural aspects that may have influenced the reception of the French rule. In particular, the linguistic proxies are meant to capture the slow-moving components of culture reflected by ancient linguistic similarities and reflect features of the local population. Instead, the rulers' attitude variables capture the cultural affinities of the ruling class with the values contained in the new transplanted institutions. Overall, the results confirm that cultural proximity plays a significant role in the acceptance of the French institutions. Consistently with the potential mechanisms discussed in the previous section, the results also suggest that various aspects of cultural distance might be relevant for a positive adoption of the transplanted institution. ${ }^{43}$

\section{CONCLUSION}

In this work, we measure how the economic impact of transplanted institutions depends on cultural proximity between the exporting and the receiving countries. Our historical context is well suited to exploiting both the quasi-natural experiment generated by the Napoleonic military campaign and cultural heterogeneity across Prussian counties. Our results show how the economic development spurred by the Napoleonic rule in Germany between the French revolution and the first half of the nineteenth century depends on culture. Specifically, we present evidence that cultural distance, measured as religious affiliation in our baseline specification, interacts with the adoption of transplanted institutions, thereby diluting the positive long-term economic effect of progressive institutions.

Drawing on novel data on pre-Napoleonic principalities combined with waves of the Prussian census we are able to conduct a comparative analysis of the economic impact of institutional transplants across areas characterized by different degrees of cultural proximity. We provide evidence that Napoleonic institutions had heterogeneous effects on economic performance across German areas characterized by different degrees of cultural proximity with France. Our results suggest that a one-standard-deviation increase in the Protestant share corresponds to a reduction in the county income of approximately $8 \%$. The magnitude of the effect is sizable and comparable to that of other significant drivers of Prussian economic growth (e.g. presence of coal deposits). Overall, our findings largely support the idea that cultural proximity facilitates the adoption of new institutions through a mix of a better disposition toward the French invader

\footnotetext{
${ }^{43}$ Section $\mathrm{A}$ in the Appendix provides the results obtained using only the subsample of invaded territories.
} 
and toward the content of the institutions in the receiving communities, and of a friendlier approach of the exporter in imposing the same formal institutions in culturally similar areas.

On a more general perspective, our results contribute to the existing debate on the so-called "Washington Consensus". Indeed, the imposition of seemingly "sound" reforms was not always beneficial for the receiving country and the reforms did not always work out the way they were intended. Although we analyze a very specific historical environment, and extrapolation to other contexts might be hazardous, our findings suggest that the new institutions are growth enhancing if designed to fit the circumstances of individual countries. In particular, reforms need to be compatible with local social norms: the transplant may fail if it conflicts with local culture, and the population may be reluctant to accept a new set of institutions that is perceived as alien or that is imposed by a culturally distant entity. 


\section{REFERENCES}

Acemoglu, D., Cantoni, D., Johnson, S., and Robinson, J. A. (2011). The Consequences of Radical Reform: The French Revolution. The American Economic Review, 101(7):3286-3307.

Acemoglu, D., Cantoni, D., Johnson, S., and Robinson, J. A. (2012). From Ancien Regime to Capitalism: The Spread of the French Revolution as a Natural Experiment. In Natural Experiments of History. Harvard University Press.

Acemoglu, D., Johnson, S., and Robinson, J. A. (2001). The Colonial Origins of Comparative Development: An Empirical Investigation. American Economic Review, 91(5):1369-1401.

Acemoglu, D., Johnson, S., and Robinson, J. A. (2002). Reversal of Fortune: Geography and Institutions in the Making of the Modern World Income Distribution. The Quarterly Journal of Economics, 117(4):12311294.

Alesina, A. and Giuliano, P. (2015). Culture and Institutions. Journal of Economic Literature, 53(4):898-944.

Alesina, A. and La Ferrara, E. (2005). Preferences for redistribution in the land of opportunities. Journal of Public Economics, 89(5-6):897-931.

Allen, R. C. (2001). The Great Divergence in European Wages and Prices from the Middle Ages to the First World War. Explorations in Economic History, 38(4):411-447.

Angrist, J. and Pischke, J. S. (2009). Mostly Harmless Econometrics. Princeton: Princeton University Press.

Arvind, T. and Stirton, L. (2010). Explaining the reception of the Code Napoleon in Germany: a fuzzy-set qualitative comparative analysis. Legal Studies, 30(1):1-29.

Becker, S. O., Cinnirella, F., Hornung, E., and Woessmann, L. (2014). iPEHD-The ifo Prussian Economic History Database. Historical Methods: A Journal of Quantitative and Interdisciplinary History, 47(2):57-66.

Becker, S. O. and Woessmann, L. (2009). Was Weber Wrong? A Human Capital Theory of Protestant Economic History. The Quarterly Journal of Economics, 124(2):531-596.

Berkowitz, D., Pistor, K., and Richard, J.-F. (2003a). Economic development, legality, and the transplant effect. European Economic Review, 47(1):165-195.

Berkowitz, D., Pistor, K., and Richard, J.-F. (2003b). The Transplant Effect. The American Journal of Comparative Law, 51(1):163-203.

Broer, M. (1996). Europe under Napoleon, 1799-1815. Hodder Education Publisher, London.

Buggle, J. C. (2016). Law and Social Capital: Evidence from the Code Napoleon in Germany. European Economic Review, 87:148-175.

Cantoni, D. (2012). Adopting a New Religion: the Case of Protestantism in 16th Century Germany. The Economic Journal, 122(560):502-531.

Cantoni, D. (2015). The Economic Effects of the Protestant Reformation: Testing the Weber Hypothesis in 
the German Lands. Journal of the European Economic Association, 13(4):561-598.

Clark, C. (2007). Iron Kingdom. The rise and downfall of Prussia 1600 - 1947. Penguin Books, London.

Crosby, M. B. (2008). The Making of a German Constitution: A Slow Revolution. Berg Publishers, Oxford.

Dal Bo, P., Foster, A., and Putterman, L. (2010). Institutions and Behavior: Experimental Evidence on the Effects of Democracy. The American Economic Review, 100(5):2205-29.

Desmet, K., Ortuno-Ortin, I., and Weber, S. (2009). Linguistic Diversity and Redistribution. Journal of the European Economic Association, 7(6):1291-1318.

Dittmar, J. and Meisenzahl, R. (2016). State capacity and public goods: Institutional change, human capital, and growth in early modern germany. Mimeo.

Donges, A., Meier, J.-M. A., and Silva, R. C. (2017). The impact of institutions on innovation. Working Paper.

Dwyer, P. G. (2000). The Rise of Prussia 1700-1830. London and New York: Routledge.

Ellis, G. (2003). The Napoleonic Empire. Palgrave Macmillan.

Falck, O., Heblich, S., Lameli, A., and Sudekum, J. (2012). Dialects, cultural identity, and economic exchange. Journal of Urban Economics, 72(2-3):225-239.

Fearon, J. D. (2003). Ethnic and cultural diversity by country. Journal of Economic Growth, 8(2):195-222.

Fehrenbach, E. (2008). Vom Ancien Regime zum Wiener Kongress. Oldenbourg, Munich.

Fernihough, A. and O'Rourke, K. H. (2014). Coal and the european industrial revolution. NBER Working Paper 19802.

Fisher, H. A. L. (1903). Studies in Napoleonic Statesmanship: Germany. Clarendon Press.

Fisman, R., Paravisini, D., and Vig, V. (2017). Cultural proximity and loan outcomes. American Economic Review, 107(2):457-492.

Galloway, P. R., Lee, R. D., and Hammel, E. A. (1994). Fertility decline in Prussia: Estimating influences on supply, demand, and degree of control. Demography, 31(2):347-373.

Galor, O., Ozak, O., and Sarid, A. (2017). Geographical Origins and Economic Consequences of Lanquage Structures. Technical report.

Glaeser, E. L. and Shleifer, A. (2002). Legal origins. Quarterly Journal of Economics, pages 1193-1229.

Guiso, L., Sapienza, P., and Zingales, L. (2009). Cultural biases in economic exchange? The Quarterly Journal of Economics, 124(3):1095-1131.

Hagemann, K. (2015). Revisiting Prussia's Wars against Napoleon: History, Culture, and Memory. Cambridge: Cambridge University Press.

Hornung, E. (2014). Immigration and the diffusion of technology: The Huguenot diaspora in Prussia. The American Economic Review, 104(1):84-122.

Keller, W. and Shiue, C. H. (2016). Market integration as a mechanism of growth. Working Paper. 
Kisch, H. (1989). From Domestic Manufacture to Industrial Revolution: The Case of the Rhineland Textile Districts: The Case of the Rhineland Textile Districts. Oxford University Press, New York.

Klein, Goldewijk, K., Beusen, A., and Janssen, P. (2010). Long term dynamic modeling of global population and built-up area in a spatially explicit way, hyde 3.1 . The Holocene, 20(4):565-573.

Kopsidis, M. and Bromley, D. W. (2016). The french revolution and german industrialization: Dubious models and doubtful causality. Journal of Institutional Economics, 12(1):161-190.

Koselleck, R. (1967). Preussen zwischen Reform und Revolution. Allgemeines Landrecht, Verwaltung und soziale Bewegung von 1791 bis 1848. Ernst Klett, Stuttgart.

La Porta, R., Lopez-de Silanes, F., and Shleifer, A. (2008). The Economic Consequences of Legal Origins. Journal of Economic Literature, 46(2):285-332.

Lefebvre, G. (1969). Napoleon. Columbia University Press, New York.

Leighton, J. (2013). Witnessing the Revolutionary and Napoleonic Wars in German Central Europe. Springer.

Lobingier, C. S. (1918). Napoleon and His Code. Harvard Law Review, 32(2):114-134.

Mailath, G. J., Morris, S., and Postlewaite, A. (2016). Laws and authority. Mimeo.

Matzerath, H. Prussia?s urbanization, 1815 to 1939. gesis data archive, cologne.

North, D. C. (1990). Institutions, institutional change and economic performance. Cambridge university press, Cambridge.

Oster, E. (2017). Unobservable selection and coefficient stability: Theory and validation. Journal of Business Economics and Statistics, forthcoming.

Parsons, T. (2010). The rule of empires: those who built them, those who endured them, and why they always fall. Oxford University Press, Oxford.

Pfohl, E. and Friedrich, E. (1928). Die Deutsche Wirtschaft in Karten (System Prof. Pfohl): 430 Karten und Diagramme uber die Deutsche Produktion in Bergbau, Industrie, Landwirtschaft. Die Standorte der Industrie, die Verteilung der Arbeiterschaft und die Stellung Deutschlands in der Weltproduktion. Berlin: Hobbing.

Pierenkemper, T. and Tilly, R. H. (2004). The German Economy During the Nineteenth Century. New York and Oxford : Berghahn Books.

Poole, R. L. (1880). A History of the Huguenots of the Dispersion at the Recall of the Edica of Nantes. Macmillan and Company, London.

Rodrik, D. (2007). One economics, many recipes. Globalization, institutions, and economic growth. Princeton: Princeton University Press.

Rowe, M. (2003). From Reich to state: the Rhineland in the revolutionary age, 1780-1830. Cambridge University Press, Cambridge.

Schleusen, K. A. (1989). Schooling and Society: The Politics of Education in Prussia and Bavaria 1750-1900. Berg Publishers, London. 
Simons, G. F. and Fennig, C. D. Ethnologue: Languages of the world, twenty-first edition, 2018.

Smets, J. (1998). Le Rhin, frontiere naturelle de la France. Annales historiques de la Revolution française, 314(1):675-698.

Smithers, W. W. (1901). The Code Napoleon. The American Law Register, 49.

Spenkuch, J. L. (2010). The Protestant Ethic and Work: Micro Evidence from Contemporary Germany. MPRA Paper 26444, University Library of Munich, Germany.

Spolaore, E. and Wacziarg, R. (2009). The diffusion of development. The Quarterly Journal of Economics, 124(2):469-529.

Spolaore, E. and Wacziarg, R. (2014). Fertility and modernity. Tufts Working Paper.

Spolaore, E. and Wacziarg, R. (2016). Ancestry, language and culture. In The Palgrave Handbook of Economics and Language, volume Chapter 6. Victor Ginsburgh and Shlomo Weber (Eds.), London: Palgrave Macmillan.

Stetson, D. M. (1987). Women's rights in France. Greenwood Press, Westport, Connecticut.

Tilly, R. H. (1966). The political economy of public finance and the industrialization of prussia, 1815-1866. The Journal of Economic History, 26(4):484-497.

Woolf, S. (2002). Napoleon's integration of Europe. Routledge.

Zweynert, J. (2011). Shock therapy and the transfer of institutions: the new debate and some lessons from the post-1806 reforms in prussia and in southwestern germany. Constitutional Political Economy, 22(2):122-140. 


\section{SUPPLEMENTAL MATERIALS TO “INSTITUTIONAL TRANS- \\ PLANT AND CULTURAL PROXIMITY: EVIDENCE FROM NINE- \\ TEENTH - CENTURY PRUSSIA” BY G. LECCE AND L. OGLIARI}

\section{A APPENDIX}

\section{Prussian counties by French Presence}

Figure A1 shows the counties in territories controlled by Napoleon differentiating between annexed areas and satellite states in our sample. All the counties under Napoleonic influence west of the Elbe river belonged either to the Duchy of Warsaw, a state established by Napoleon in 1807 after the Treaty of Tilsit, or to the Republic of Danzig, a semi-independent city-state established by Napoleon on 9 September 1807. We consider the German northwest territories (the Duchy of Arenberg) as satellite states even though they were later annexed, in December 1810, by the French Empire. 
Figure A1: Counties Under Napoleonic Influence

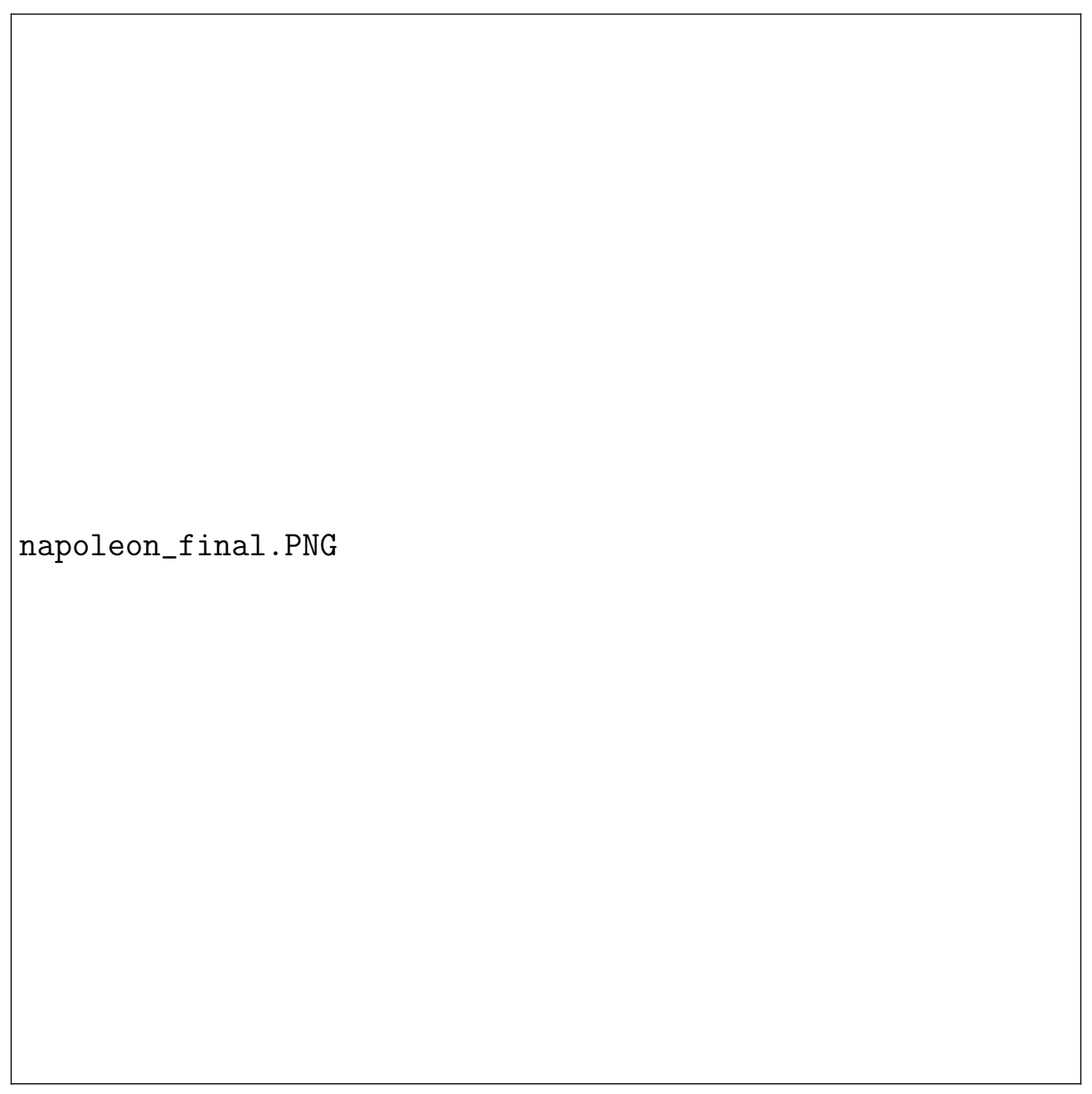




\section{Summary Statistics by Napoleonic Treatment and Complete Base-}

\section{line Specification}

We start this section by presenting summary statistics separately for invaded and not-invaded territories to better gauge the characteristics of the treatment and the control groups in Table A1. As expected, the comparison shows that invaded areas tend to be on average more developed than the not-invaded ones and, while demographic characteristics are comparable across the two groups, the not-invaded areas display a higher share of Protestants in the county population. In Table A2 we follow Donges et al. (2017) and test whether we can predict either the probability of falling under French influence or the duration of the French rule with pre-1789 variables that account for geographic and economic characteristics. The suggestive findings corroborate the anecdotal evidence that Napoleonic military campaigns were not driven by the economic prospects of the invaded areas but rather by geo-political and ideological reasons. ${ }^{44}$ In Table A3 we report the complete set of estimated coefficients of the specifications reported in Table 3.

Table A1: Summary Statistics (by Counties with/without French Institutions)

\begin{tabular}{lccccc}
\hline Variable & Mean & Std. Dev. & Min. & Max. & N \\
\hline PANEL: NO FRENCH INSTITUTIONS & & & & & \\
Income of male elem. school teachers (1886) & 938.234 & 177.887 & 722.221 & 1954.194 & 209 \\
Protestant Share & 0.772 & 0.315 & 0.016 & 0.999 & 209 \\
\% of county population in urban areas & 0.255 & 0.193 & 0 & 1 & 209 \\
\% females & 0.515 & 0.012 & 0.467 & 0.541 & 209 \\
\% age below 10 & 0.248 & 0.025 & 0.158 & 0.297 & 209 \\
Total Population (log) & 10.873 & 0.393 & 9.768 & 13.625 & 209 \\
County Area (log) & 11.017 & 0.969 & 5.989 & 12.899 & 209 \\
University in 1517 & 0.005 & 0.069 & 0 & 1 & 209 \\
Hanseatic or Imperial City & 0.053 & 0.224 & 0 & 1 & 209 \\
Coal Deposits & 0.196 & 0.398 & 0 & 1 & 209 \\
PANEL: FRENCH INSTITUTIONS & & & & & \\
Income of male elem. school teachers (1886) & 1022.542 & 212.517 & 711.961 & 1838.763 & 238 \\
Protestant Share & 0.532 & 0.391 & 0.003 & 0.998 & 238 \\
\% of county population in urban areas & 0.294 & 0.24 & 0 & 1 & 238 \\
\% females & 0.506 & 0.016 & 0.44 & 0.546 & 238 \\
\% age below 10 & 0.246 & 0.025 & 0.153 & 0.299 & 238 \\
Total Population (log) & 10.743 & 0.427 & 9.359 & 11.91 & 238 \\
County Area (log) & 10.605 & 1.263 & 5.313 & 12.955 & 238 \\
University in 1517 & 0.038 & 0.191 & 0 & 1 & 238 \\
Hanseatic or Imperial City & 0.139 & 0.346 & 0 & 1 & 238 \\
Coal Deposits & 0.34 & 0.475 & 0 & 1 & 238 \\
\hline
\end{tabular}

\footnotetext{
${ }^{44}$ We find a negative correlation between years of French invasion and coal deposits. However, this correlation arises only when including the entire set of geographical controls in the specification, while the simple correlation between our institutional variable and the coal deposits is positive.
} 
Table A2: Exogeneity Test - Napoleonic Invasion and Socioeconomic Drivers

\begin{tabular}{lcccc}
\hline Dependent Variable & $\begin{array}{c}\text { Napoleon } \\
(1)\end{array}$ & $\begin{array}{c}\text { Napoleon } \\
(2)\end{array}$ & $\begin{array}{c}\text { Years of French Inv. } \\
(3)\end{array}$ & $\begin{array}{c}\text { Years of French Inv. } \\
(4)\end{array}$ \\
\hline Urb. Rate - 1790 & -0.0101 & -0.0295 & -1.084 & -0.860 \\
& $(0.134)$ & $(0.126)$ & $(1.377)$ & $(1.283)$ \\
Pop.Density - 1790 & 0.000368 & 0.000957 & -0.0113 & 0.000820 \\
& $(0.000925)$ & $(0.000755)$ & $(0.00896)$ & $(0.00581)$ \\
City population in 1500 & 6.490 & 6.613 & 98.98 & $104.6^{*}$ \\
& $(5.499)$ & $(5.899)$ & $(66.56)$ & $(59.95)$ \\
Educational Centers & $0.187^{* * *}$ & 0.0706 & 1.228 & -0.648 \\
& $(0.0541)$ & $(0.0626)$ & $(0.801)$ & $(0.751)$ \\
Hanseatic or Imperial City & $0.165^{* * *}$ & 0.112 & 0.731 & -0.0746 \\
& $(0.0632)$ & $(0.0689)$ & $(0.838)$ & $(0.718)$ \\
Coal Deposits & -0.00619 & -0.0212 & $-1.159^{* * *}$ & $-1.297^{* * *}$ \\
& $(0.0462)$ & $(0.0422)$ & $(0.585)$ & $(0.469)$ \\
\hline Geographic Controls & yes & yes & yes & yes \\
Distance Controls & no & yes & no & yes \\
$R^{2}$ & 0.336 & 0.447 & 0.371 & 0.596 \\
Obs. & 413 & 413 & 413 & 413 \\
\hline
\end{tabular}

Notes: The dependent variable is in the column heading. Geographic Controls: latitude, area of the county (log) and Polish-speaking area. Distance Controls: distance from Paris, distance from the imperial capital (Berlin), distance from the district capital. Robust standard errors in parentheses. ${ }^{* * *} \mathrm{p}<0.01,{ }^{* *} \mathrm{p}<0.05,{ }^{*} \mathrm{p}<0.1$ 
Table A3: Baseline Specification

\begin{tabular}{|c|c|c|c|c|c|}
\hline $\begin{array}{l}\text { Log Average Wage for } \\
\text { Male Elementary Teachers in } 1886\end{array}$ & (1) & (2) & (3) & (4) & (5) \\
\hline \multirow[t]{2}{*}{ Napoleon } & $0.0377^{* *}$ & $0.114^{* * *}$ & $0.109^{* * *}$ & $0.121^{* * *}$ & -0.595 \\
\hline & $(0.0172)$ & $(0.0224)$ & $(0.0220)$ & $(0.0278)$ & $(0.813)$ \\
\hline \multirow[t]{2}{*}{ Protestant Share } & $0.0938^{* * *}$ & $0.172^{* * *}$ & $0.184^{* * *}$ & $0.170^{* * *}$ & $0.190^{* * *}$ \\
\hline & $(0.0189)$ & $(0.0261)$ & $(0.0254)$ & $(0.0330)$ & $(0.0401)$ \\
\hline \multirow[t]{2}{*}{ Napoleon $\times$ Protestant Share } & & $-0.112^{* * *}$ & $-0.121^{* * *}$ & $-0.174^{* * *}$ & $-0.208^{* * *}$ \\
\hline & & $(0.0332)$ & $(0.0325)$ & $(0.0335)$ & $(0.0403)$ \\
\hline \multirow{2}{*}{ Polish-speaking provinces } & $-0.0416^{* * *}$ & $-0.0366^{* * *}$ & $-0.0377^{* * * *}$ & $-0.0281^{*}$ & -0.0243 \\
\hline & $(0.0143)$ & $(0.0139)$ & $(0.0137)$ & $(0.0157)$ & $(0.0217)$ \\
\hline \multirow[t]{2}{*}{ Latitude in radius ${ }^{*} 100$} & -0.00458 & $-0.00686^{*}$ & $-0.0111^{* * *}$ & -0.00315 & -0.00751 \\
\hline & $(0.00381)$ & $(0.00400)$ & $(0.00426)$ & $(0.00365)$ & $(0.00622)$ \\
\hline \multirow[t]{2}{*}{ County Area (log) } & $-0.0780^{* * *}$ & $-0.0767^{* * *}$ & $-0.0695^{* * *}$ & $-0.0869^{* * *}$ & $-0.0850^{* * *}$ \\
\hline & $(0.00762)$ & $(0.00756)$ & $(0.00898)$ & $(0.0136)$ & $(0.0173)$ \\
\hline \multirow[t]{2}{*}{ Coal Deposits } & $0.0828^{* * *}$ & $0.0845^{* * *}$ & $0.0783^{* * *}$ & 0.0121 & -0.0302 \\
\hline & $(0.0172)$ & $(0.0172)$ & $(0.0167)$ & $(0.0131)$ & $(0.0220)$ \\
\hline \multirow[t]{2}{*}{ Imperial city in 1517} & & & 0.0412 & -0.00246 & $-0.116^{* *}$ \\
\hline & & & $(0.0340)$ & $(0.0272)$ & $(0.0486)$ \\
\hline \multirow[t]{2}{*}{ Hanseatic city in 1517} & & & $0.0865^{* * *}$ & 0.0116 & -0.00607 \\
\hline & & & $(0.0327)$ & $(0.0234)$ & $(0.0308)$ \\
\hline \multirow[t]{2}{*}{ City population in 1500} & & & 1.105 & 1.313 & 7.194 \\
\hline & & & $(1.373)$ & $(1.486)$ & $(14.16)$ \\
\hline \multirow{2}{*}{ Number of Farms $1882(\log )$} & & & & $0.0689^{* * *}$ & $0.0641^{* * *}$ \\
\hline & & & & $(0.0163)$ & $(0.0185)$ \\
\hline \multirow[t]{2}{*}{$\%$ of Labor Force in Mining } & & & & 0.112 & 0.107 \\
\hline & & & & $(0.0855)$ & $(0.0831)$ \\
\hline \multirow[t]{2}{*}{$\%$ of County Population in Urban Areas } & & & & $0.293^{* * *}$ & $0.298^{* * *}$ \\
\hline & & & & $(0.0437)$ & $(0.0500)$ \\
\hline \multirow[t]{2}{*}{ Total Population (log) } & & & & 0.0165 & 0.0190 \\
\hline & & & & $(0.0329)$ & $(0.0390)$ \\
\hline \multirow[t]{2}{*}{ Year in which annexed by Prussia } & & & & $0.000166^{* * *}$ & $0.000182^{* *}$ \\
\hline & & & & $(5.74 \mathrm{e}-05)$ & $(7.25 \mathrm{e}-05)$ \\
\hline \multirow[t]{2}{*}{$\%$ Jews } & & & & $-1.816^{* * *}$ & $-1.523^{* *}$ \\
\hline & & & & $(0.481)$ & $(0.636)$ \\
\hline Distance to Berlin in km & & & & $-9.86 \mathrm{e}-05^{* *}$ & $-9.81 e-05^{*}$ \\
\hline & & & & $(4.86 \mathrm{e}-05)$ & $(5.18 \mathrm{e}-05)$ \\
\hline Dist. to District Capital & & & & -0.000204 & -0.000135 \\
\hline & & & & $(0.000162)$ & $(0.000161)$ \\
\hline \# free apartment for teachers & & & & -0.000162 & $-7.82 \mathrm{e}-05$ \\
\hline & & & & $(0.000226)$ & $(0.000270)$ \\
\hline$\%$ Pupils with Dist. to School over $3 \mathrm{~km}$ & & & & -0.341 & -0.316 \\
\hline & & & & $(0.218)$ & $(0.195)$ \\
\hline (log) \# of Teachers & & & & -0.0511 & -0.0476 \\
\hline & & & & $(0.0411)$ & $(0.0454)$ \\
\hline (log) \# of Pupils & & & & $0.117^{* * *}$ & $0.106^{* *}$ \\
\hline & & & & $(0.0413)$ & $(0.0426)$ \\
\hline Napoleon $\times$ City population & & & & & -6.492 \\
\hline Napoleon $\times$ Hanseatic city & & & & & $\begin{array}{l}(14.26) \\
0.0234\end{array}$ \\
\hline 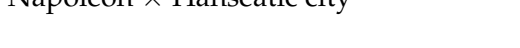 & & & & & $(0.0520)$ \\
\hline Napoleon $\times$ Imperial city & & & & & $0.124^{* *}$ \\
\hline & & & & & $(0.0620)$ \\
\hline Napoleon $\times$ Polish-speaking provinces & & & & & -0.0408 \\
\hline & & & & & $(0.0365)$ \\
\hline Napoleon $\times$ Latitude & & & & & 0.00773 \\
\hline & & & & & $(0.00910)$ \\
\hline Napoleon $\times$ County Area (log) & & & & & 0.00230 \\
\hline & & & & & $(0.0151)$ \\
\hline Napoleon $\times$ Coal Deposits & & & & & $0.0639^{* *}$ \\
\hline & & & & & $(0.0276)$ \\
\hline$R^{2}$ & 0.396 & 0.406 & 0.429 & 0.667 & 0.677 \\
\hline Obs. & 447 & 447 & 447 & 447 & 447 \\
\hline
\end{tabular}

Notes: Robust standard errors in parenthesis. ${ }^{* *} \mathrm{p}<0.01,{ }^{* *} \mathrm{p}<0.05,{ }^{*} \mathrm{p}<0.1$ 


\section{Robustness Checks}

This section presents a series of checks to verify the robustness of the baseline estimates. First, we use different proxies for the dependent variable. Then, we test our model specification by adding both historical and contemporaneous controls, using different clustering and performing the analysis on different samples. The coefficients of the interaction terms $\beta_{3}$ obtained implementing our baseline specification (Equation 1) are reported in Table A4.

Dependent Variable Panel a) of Table A4 shows that the baseline results hold for alternative proxies for economic prosperity. In row (1), we use the average income of male elementary school teachers in levels. The results are consistent with the baseline model, and the interaction term is statistically significant and negative. The coefficients differ in terms of magnitude compared to our main specification wherein the dependent variable is measured as the logarithm. In row (2), we use another direct measure of income, that is, the log wage of a daily laborer in $1892 .{ }^{45}$ Then, as in Becker and Woessmann (2009), we use income tax revenue per capita as the dependent variable in row (3). Finally, in row (4) we use Prussian urbanization data made available by Matzerath. We matched approximately 400 counties with the reported administrative regions and use the urbanization rate in 1871 as the dependent variable. In the specification we also control for the urbanization in 1816, and the total county population (in level) reported by the official statistics in 1816 and $1871 .{ }^{46}$ The coefficients of the interaction terms remain consistently negative and statistically significant.

Protestant Variable Panel b) focuses on the religious affiliation measure. First, to rule out the possibility that the results are affected by minor changes in the Protestant share variable, we use a Protestant (absolute) majority dummy (row 5). Note that the coefficients have the same sign as in the baseline specification, and they remain significant at conventional levels. We then compute the Protestant share using the first available wave of the Prussian census, which was conducted in 1816 immediately after the Congress of Vienna. While this variable is available only for the 349 counties that formed Prussia at that time, its correlation with the Protestant share in 1871 is extremely high (0.98). ${ }^{47}$ Accordingly, our main results are unchanged (row 6). Third, one may still worry that the persistence of religious affiliation after the Napoleonic wars is not sufficiently informative of the religious composition at the end of the eighteenth century given that

\footnotetext{
${ }^{45}$ Table A4 displays the results for male laborers in urban areas. The coefficients are virtually the same when using the wage of a rural male daily laborer or the wage of a female daily laborer. These results are available upon request.

${ }^{46}$ The sample is significantly reduced because of the match with the urbanization data and the different institutional environment in 1816 (Prussia had a smaller territory, see also row 6).

${ }^{47}$ Of the invaded territories, Prussia was given the Rhineland and the Duchy of Warsaw. All states that we consider satellites remained independent after the Congress of Vienna and were annexed by the Kingdom of Prussia only later.
} 
war itself may have caused religious migration. To address this concern, we construct a historical measure of the Protestant majority in the seventeenth century using data from Cantoni (2012) and Spenkuch (2010). Although it is defined at the principality (rather than at the county) level, and it is not available for the entire sample, the advantage of this variable is that it was measured two centuries before the arrival of Napoleon. The main evidence is unaffected even when using the historical Protestant dummy (row 7). Finally, we follow the literature and instrument the Protestant share using the distance from Wittenberg. This should isolate exogenous variation in religious affiliation using the concentric diffusion of Protestantism through Prussia from its origins in Luther's city (row 8 ). ${ }^{48}$ The results are qualitatively unchanged, and the coefficient of interest is even larger than that for the baseline estimate.

Additional Controls In panel c), we introduce additional controls that may affect our results. One potential concern is that pre-Napoleonic differences in the economic prosperity of the counties are not fully accounted by the baseline controls. We hence retrieve population and urbanization data in 1790 from the History Database of the Global Environment, and we construct measures of population densities and urbanization before the Napoleonic invasion (row 9). ${ }^{49}$ Another possible concern is that our result is induced by differences in purchasing power across regions or by other drivers of the demand for teachers and, consequently, of their wages. Hence, we first include a price measure to capture potential differences in purchasing power across counties (row 10). This proxy is constructed as the ratio of total expenditures on new school buildings in 1886 to the total number of new school buildings, which should capture variation in housing prices. We then add a group of sociodemographic variables from 1871 - including household size, the share of females and the share of the population under 16 - that might influence the demand for teachers. We also include the share of the population of Prussian origin and the share of the population born in the county to control for the stock of both internal and foreign migrants (row 11). Finally we add the literacy rate to control for the value that people in different counties attribute to schooling (row 12). The latter control is of particular importance for Protestant areas where, on average, the literacy rate is higher. In row 13, rather than using total number of pupils and teachers, which might capture population size, we used alternative education measures as enrollment rates and student-teacher ratios in 1886. Finally we include a dummy variable that captures the presence of ore deposits (row 14). We construct this dummy variable from the map BII (metal ore mining) in Pfohl and Friedrich (1928). The results consistently confirm the baseline estimates. ${ }^{50}$

\footnotetext{
${ }^{48}$ The $t$-statistic of the first stage is approximately 14 .

${ }^{49}$ This data, compiled by the PBL Netherlands Environmental Assessment Agency, are available at 0.5 by 0.5 degree grid. We construct population density by summing information on population of all the cells belonging to each county and dividing by the county area. Similarly, we construct urbanization rates by summing cell-level information on people living in urban areas and dividing it by total population.

${ }^{50}$ The magnitude of the coefficient halves when using religious affiliation as our cultural distance proxy mainly due to the inclusion of literacy rate. Nonetheless, the robustness of the coefficients is confirmed by
} 
Clustering To allow for an arbitrary variance-covariance matrix capturing potential serial correlation in the residual error term, panel d) considers clustered standard errors at the pre-Napoleonic-principality level (row 15); at the pre-Napoleonic-ruler level (row 16), since many principalities were under the control of the same authority; at the pre-unitary-state level after the Napoleonic German Mediatization, as defined by Acemoglu et al. (2011) (row 17); and at the Prussian political-district level in 1871 (row 18). The coefficients of interest are always statistically significant, as in the baseline estimates.

Samples Finally, in panel e), we show that our evidence is not driven by influential observations. First, we trim (row 19) and winsorize (row 20) the extreme $1 \%$ of observations of our dependent variable. In row (21), we compute a measure of the influence of each observation on the estimated coefficient. In particular, an observation is considered influential when the difference between the regression coefficient estimated using the whole sample and that calculated excluding the observation is above a standard cutoff value. ${ }^{51}$ We then exclude all the influential observations for the coefficient of interest (Napoleon $\times$ Linguistic Distance or Napoleon $\times$ Protestant Share or Napoleon $\times$ No French Ties). Moreover, in rows (22)-(26), we consider alternative subsamples. In row (22), we exclude Polish-speaking areas, as these territories are mostly Catholic and have below-average economic performance. We then exclude the Duchy of Nassau (row 23), since it joined the Confederation of the Rhine but did not implement the Code despite formally adopting it. (See Arvind and Stirton (2010)). Then, we exclude the territories under the direct control of the French Empire and consider as treated only those territories in the Confederation of the Rhine (i.e., satellite states) that adopted the Code (row 24) in order to exclude the possibility that our results are mainly driven by the Rhineland. We also exclude territories annexed after 1810 (row 25) because they were under French influence for only a few months. Finally, in row (26), of the territories under the control of Napoleon, we keep only those annexed by the French Empire. Although the resulting sample contains only approximately $60 \%$ of the original observations, the sign of the coefficient on the interaction term is always negative, and statistically significant.

Overall, the results obtained using different samples show that the interaction between institutions and cultural distance is statistically significant, has the expected sign and is remarkably stable.

the results of Oster tests. The bias-adjusted estimated effect of the interaction term, Napoleon $\times$ Protestant Share, is always strictly negative and much larger than the OLS estimate (Oster, 2017), suggesting that the degree of omitted variable bias is unlikely to explain the size of the estimated effect.

${ }^{51}$ The cut-off value we use for a highly influential observation is $2 / \sqrt{(n)}$, but our results are robust to the use of different cut-offs. 
Table A4: Robustness Checks - Specification

\begin{tabular}{|c|c|c|c|c|}
\hline & \multicolumn{4}{|c|}{ Nap. $\times$ Ling. Dist. } \\
\hline & Coeff. & s.e. & Obs. & $R^{2}$ \\
\hline \multicolumn{5}{|l|}{ a) Dependent Variable } \\
\hline 1) Wage Elem. Teacher (level) & $-216.3^{* * *}$ & $(46.65)$ & 447 & 0.675 \\
\hline 2) Wage Urb. Male Lab. 1892 (log) & $-0.236^{* * *}$ & $(0.0545)$ & 430 & 0.686 \\
\hline 3) Income Tax Revenue p.c. 1877 & $-0.806^{* * *}$ & $(0.200)$ & 421 & 0.384 \\
\hline 4) Urbanization 1871 & $-6.652^{* *}$ & $(2.654)$ & 291 & 0.985 \\
\hline \multicolumn{5}{|l|}{ b)Protestant Variable } \\
\hline 5) Protestant Dummy & $-0.124^{* * *}$ & $(0.0274)$ & 447 & 0.666 \\
\hline 6) Protestant Share 1816 & $-0.144^{* * *}$ & $(0.0323)$ & 349 & 0.859 \\
\hline 7) Protestant Dummy 1600 & $-0.149^{* *}$ & $(0.0756)$ & 438 & 0.668 \\
\hline 8) IV Distance from Wittemberg & $-0.669^{* * *}$ & $(0.127)$ & 447 & 0.354 \\
\hline \multicolumn{5}{|l|}{ c) Additional Controls } \\
\hline 9) Pop Density \& urb. rate 1790 & $-0.208^{* * *}$ & $(0.0438)$ & 413 & 0.682 \\
\hline 10) Price (Real estate unit price) & $-0.204^{* * *}$ & $(0.0418)$ & 441 & 0.675 \\
\hline 11) Socio-Demographic & $-0.139^{* * *}$ & $(0.0474)$ & 447 & 0.705 \\
\hline 12) Literacy & $-0.138^{* * *}$ & $(0.0377)$ & 447 & 0.702 \\
\hline 13) Educational Proxies & $-0.189^{* * *}$ & $(0.803)$ & 447 & 0.683 \\
\hline 14) Ore Deposits & $-0.208^{* * *}$ & $(0.0408)$ & 447 & 0.677 \\
\hline \multicolumn{5}{|l|}{ d) Clustering Levels } \\
\hline 15) Pre-Napoleonic Principality & $-0.208^{* * *}$ & $(0.0692)$ & 447 & 0.677 \\
\hline 16) Pre-Napoleonic Ruler & $-0.208^{* * *}$ & $(0.0626)$ & 447 & 0.677 \\
\hline 17) Post-Napoleonic Kingdom & $-0.208^{* * *}$ & $(0.0516)$ & 447 & 0.677 \\
\hline 18) District 1871 & $-0.208^{* * *}$ & $(0.0499)$ & 447 & 0.677 \\
\hline \multicolumn{5}{|l|}{ e) Alternative Samples } \\
\hline 19) Trimming (1\%) & $-0.203^{* * *}$ & $(0.0318)$ & 439 & 0.674 \\
\hline 20) Winsorising (1\%) & $-0.205^{* * *}$ & $(0.0375)$ & 447 & 0.680 \\
\hline 21) Df Beta & $-0.241^{* * *}$ & $(0.0279)$ & 426 & 0.728 \\
\hline 22) Excluding Polish-speaking Areas & $-0.260^{* * *}$ & $(0.0574)$ & 328 & 0.660 \\
\hline 23) Excluding Duchy of Nassau & $-0.238^{* * *}$ & $(0.0407)$ & 438 & 0.704 \\
\hline 24) Excluding Rhineland & $-0.186^{* * *}$ & $(0.0440)$ & 395 & 0.673 \\
\hline 25) Excluding Areas Annexed after 1810 & $-0.232^{* * *}$ & $(0.0422)$ & 411 & 0.696 \\
\hline 26) Excluding Confederation of the Rhine & $-0.190^{* *}$ & $(0.0847)$ & 261 & 0.720 \\
\hline
\end{tabular}

Notes: The dependent variable is the logarithm of the average annual wage of an elementary school teacher in 1886, unless otherwise specified in the table. All specifications include Geographic Controls, Historical Controls, Socioeconomic Controls, Education Controls and Hist \& Geo Interactions. See also, the notes to Table 3. Robust standard errors in parentheses, unless otherwise specified in the table.

${ }^{* * *} \mathrm{p}<0.01,{ }^{* *} \mathrm{p}<0.05,{ }^{*} \mathrm{p}<0.1$ 


\section{Omitted Variables: Fixed Effect Specification}

A potential concern with our identification strategy is that the presence of unobserved characteristics may influence both economic outcomes and cultural traits. In this section, we address this issue by conditioning on a series of different fixed effects. Specifically, we add a set of ruler fixed effects and three groups of geographic dummies to the baseline specification. This allows us to take into account all pre-Napoleonic principality-level characteristics (e.g., institutional setting) and exploit only the within-region variation in the explanatory variables. The latter can be attributed to the eventful history of the Holy Roman Empire, where recurring wars, alliances and inheritances periodically reshaped political borders. Table A5 reports the results.

The first set of fixed effects we include is defined at the ruler level (Ruler FE) and controls for all features common to territories under the same ruler (e.g., institutional reforms, legal framework). We identify 18 different rulers at the time of the Napoleonic invasions and include a dummy for each of them (column 1). ${ }^{52}$ Identification now relies on cross-county variation in Protestant share within a ruler's land. ${ }^{53}$ The coefficient of interest, although slightly smaller, is negative and statistically significant when we exploit within-ruler variation, suggesting that the economic effect of French institutions crucially relies on the cultural background.

To further tackle this issue, we compute the distance quintiles between each county and Berlin, Paris or the closest French Border and include a dummy variable for each quintile. The results are reported respectively in columns (2), (3) and (4). Reassuringly, the estimated coefficient on the interaction term has the expected sign, and it is significant across all specifications. Adding the distance dummies, especially the distance from the French border, occasionally reduces the magnitude of this coefficient. This is not surprising given that the distance from the French border also captures the trajectory and timing of the military expansion of the French Empire and, thus, the intensity of the treatment.

\footnotetext{
${ }^{52}$ As noted above, several principalities were under the same ruler; thus, the number of ruler fixed effects, 18 , is smaller than the number of principalities, 36 .

${ }^{53}$ Notice that we observe the Protestant share at a lower level of aggregation (county level) than the principality. We thereby exploit within-principality religious variation for identification.
} 
Table A5: Fixed Effects Specification

\begin{tabular}{lcccc}
\hline $\begin{array}{l}\text { Log Average Wage of a } \\
\text { Male Ele. School Teacher (1886) }\end{array}$ & $(1)$ & $(2)$ & $(3)$ & $(4)$ \\
\hline Napoleon & -0.320 & -0.453 & -0.499 & -0.0400 \\
& $(0.658)$ & $(0.790)$ & $(0.787)$ & $(0.829)$ \\
Protestant Share & $0.131^{* * *}$ & $0.200^{* * *}$ & $0.119^{* * *}$ & $0.110^{* * *}$ \\
& $(0.0290)$ & $(0.0433)$ & $(0.0425)$ & $(0.0369)$ \\
Napoleon $\times$ Protestant Share & $-0.0884^{* *}$ & $-0.208^{* * *}$ & $-0.0801^{*}$ & $-0.0623^{*}$ \\
& $(0.0381)$ & $(0.0404)$ & $(0.0453)$ & $(0.0367)$ \\
\hline Specification & Ruler FE & Dist. Berlin & Dist. Paris & Dist. French Border \\
$R^{2}$ & 0.794 & 0.681 & 0.735 & 0.732 \\
Obs. & 447 & 447 & 447 & 447 \\
\hline
\end{tabular}

Notes: The dependent variable is the logarithm of the average annual wage of an elementary school teacher in 1886. All specifications include Geographic Controls, Historical Controls, Socioeconomic Controls, Education Controls and Hist $\mathcal{E}$ Geo Interactions. See also, the notes to Table 3. Robust standard errors in parentheses.

${ }^{* * *} \mathrm{p}<0.01,{ }^{* *} \mathrm{p}<0.05,{ }^{*} \mathrm{p}<0.1$ 


\section{Intensity of the Institutional Treatment}

In this section, we investigate how the moderating effect of cultural distance changes with the length of exposure to the new institutions. In Section, we thoroughly discuss the differences in implementation that are partially due to the timing of the military campaign. It could be that a longer (or more intense) exposure to the new institution reduces the importance of cultural distance in the transplantation process, as the new rules have more time to cement. To explore this question, in Table A6, we use three measures that capture different facets of the intensity of the institutional treatment.

First, we differentiate between territories that were annexed by the French Empire and those belonging to the Confederation of the Rhine (i.e., satellite states). In the former group, the effects of treatment might be stronger, not only because the Code was imposed and fully implemented but also because the administrative structure and local governors were replaced with French ones. Moreover, when considering the years of French invasion, the annexed territories are those with the longest period of exposure to the French institutions: 19 years compared to 6 years for the majority (96\%) of the counties belonging to satellite states. Column (1) shows that the coefficients on the interaction terms remain negative and significant. Although the coefficients on the interaction terms are not statistically different when we distinguish between annexed territories and satellite states, our findings suggest that cultural distance has a slightly larger impact on the effect of the new institutions on economic performance in places where the strength of the authority enforcing the institutional reforms was higher.

Second, we use the number of years of French influence. Again, we want to capture the differences in exposure to French institutions. The coefficients reported in column (2) confirm that more years under French rule imply a stronger negative effect when the Protestant share is high. 
Table A6: Intensity of Treatment

\begin{tabular}{|c|c|c|c|}
\hline $\begin{array}{l}\text { Log Average Wage of a } \\
\text { Male Ele. School Teacher (1886) }\end{array}$ & (1) & (2) & (3) \\
\hline Protestant Share & $\begin{array}{l}0.194^{* * *} \\
(0.0407)\end{array}$ & $\begin{array}{l}0.140^{* * *} \\
(0.0388)\end{array}$ & $\begin{array}{l}0.371^{* * *} \\
(0.0671)\end{array}$ \\
\hline Prot. Share $\times$ Fr.Empire & $\begin{array}{l}-0.219^{* * *} \\
(0.0756)\end{array}$ & & \\
\hline Prot. Share $\times$ Satellite & $\begin{array}{l}-0.172^{* * *} \\
(0.0426)\end{array}$ & & \\
\hline Prot. Share $\times$ Years of French & & $\begin{array}{l}-0.0120^{* *} \\
(0.00479)\end{array}$ & \\
\hline Prot. Share $\times$ ACJR Ind. & & & $\begin{array}{c}-0.00611^{* * *} \\
(0.00116)\end{array}$ \\
\hline $\begin{array}{l}R^{2} \\
\text { Obs. }\end{array}$ & $\begin{array}{c}0.692 \\
447\end{array}$ & $\begin{array}{c}0.673 \\
447\end{array}$ & $\begin{array}{c}0.683 \\
431\end{array}$ \\
\hline \multicolumn{4}{|c|}{$\begin{array}{l}\text { Notes: The dependent variable is the logarithm of the average annual } \\
\text { wage of an elementary school teacher in } 1886 \text {. All specifications in- } \\
\text { clude Geographic Controls, Historical Controls, Socioeconomic Controls, } \\
\text { Education Controls and Hist } \mathcal{E} \text { Geo Interactions. See also the notes to } \\
\text { Table } 3 \text {. Robust standard errors in parentheses. }\end{array}$} \\
\hline
\end{tabular}

Third, we use an index proposed by Acemoglu et al. (2011) that summarizes different reforms: the enactment of the French Civil Code, the restructuring of agricultural relations, the abolition of guilds and the abolition of serfdom (column 3). This index is derived by simply adding up the total number of years prior to 1871 (the year of the German unification) in which each of the four reforms had been in effect and then dividing this total number of years by four. Higher values of the indexes reflect a longer exposure to progressive reforms. With the caveat in mind that the duration of the reforms might not be fully exogenous, the estimate seems to confirm that a more intense exposure to progressive institutions (i.e., longer duration and higher number of reforms) had a weaker impact on economic performance in Protestant areas. The overall findings suggest that cultural distance continues to play a significant role even when the intensity of the institutional treatment increases. 


\section{Competing Explanations}

This section investigates alternative explanations for our findings. We focus on factors, other than culture, that may interact with the new institutions, thereby affecting long-run economic outcomes. The coefficients of interest are reported in Table A7.

State Capacity Dittmar and Meisenzahl (2016) provide evidence on the links between Protestantism, enhanced state capacity and growth. In particular, they show that the 103 reformed cities that boosted public good provision in the sixteenth century by adopting city-level laws, called church ordinances (kirchnordnung), experienced significantly higher population growth in the long run. The coefficients on the interaction between cultural proximity, especially when measured by religious affiliation, and institutions may be explained by the fact that French institutions were ineffective in counties with high levels of public good provision, since they already had good institutions. This could be true if the pre-existing and new institutions are substitutes. In order to rule out this possibility, we collect data on the kirchnordnung, following Dittmar and Meisenzahl (2016). Specifically, we identify 45 cities in our sample that adopted this particular legal institution in the sixteenth century, and we construct a dummy variable (Church Ordinances) that equals one if at least one city in the county promulgated a kirchnordnung. ${ }^{54}$ The results reported confirm the hypothesis that counties with institutionalized public good provision were on a higher growth path, as the coefficient on Church Ordinances is positive and significant. Importantly, however, the results also show that the interaction between the measure of state capacity and French institutions has a small and not always significant coefficient. Accordingly, including this interaction in the main specifications does not alter our results (column 1).

Institutional Proximity Our results might be induced by institutional rather than cultural proximity. During the eighteenth century, some rulers, perhaps inspired by Enlightenment principles, enacted reforms in their states to promote literacy and simplify justice and administration (See Arvind and Stirton, 2010). It is possible that by the time Napoleon arrived, the local population was already used to a modern legal framework in places where these early reforms were implemented and was, hence, more likely to accept Napoleonic institutions. In order to disentangle the contribution of institutional similarity from that of cultural commonality in moderating the economic effect of the transplant, we construct a measure of historical institutional proximity. In particular, we collect data on progressive reforms of the educational, judicial or administrative systems implemented in each state between 1701 and 1790. We classify rulers who implemented at least one modernizing reform as Reformists, and we create a dummy variable that equals one if the principality had at least one Reformist ruler between 1701 and 1790. The coefficient on the interaction

\footnotetext{
${ }^{54}$ The geographical area we examine does not perfectly overlap with that analyzed by Dittmar and Meisenzahl (2016). Approximately one-half of the cities they consider are included in our sample.
} 
term Reformist $\times$ Cultural dist shows that the similarities of Napoleonic institutions with pre-existing ones positively affect the success of the transplant. However, our coefficients of interest remain negative, highly significant, and similar in magnitude to those of the baseline specification, confirming that cultural traits in particular, cultural proximity - play a role beyond pre-existing institutional characteristics.

Legitimacy of the Pre-Napoleonic Ruler The intricate web of family ties characterizing the European aristocracy, coupled with complex succession laws, implied that the same prince frequently ruled several occasionally non-contiguous - principalities. This implied prolonged absences that could erode the ruler's legitimacy and, in turn, entail various degrees of reception of new institutions. In addition to the inclusion of ruler fixed effects in Table A5, we explore this possible alternative explanation by constructing a dummy variable, Peripheral Ruler, which identifies 21 peripheral principalities (277 counties) with respect to the ruler's main residence. For example, Charles Theodore (1724-1799) was Prince Elector of Bavaria, where he maintained his main residence, but he also ruled the Electorate Palatinate and Duchy of Julich and Berg. For those three territories, the Peripheral Ruler dummy takes the value 1 in our sample. Reassuringly, column (3) confirms that our results are not affected by the physical presence of the ruler.

Education Policies Among other reforms, Napoleon restructured the educational system. His main objective was to breed well-prepared military and administrative elites, and his interventions principally targeted higher education, leaving primary schooling in the hands of Catholic religious institutions and old local-community schools. ${ }^{55}$ A fruitful interaction could have arisen where an already-developed primary education system was combined with innovative Napoleonic educational policies. In order to test this potential channel, we use information on the presence of schools and monasteries - the most prominent primary educational centers at the time - in 1517. We define a dummy variable that takes the value 1 if a school or a monastery was present in the county and interact this variable with our institutional measure. In order to control for pre-existing hubs of higher education, we also include a dummy variable identifying the presence of universities in the county before the Napoleonic invasions. The results show that the presence of educational centers does not generate any synergy with the Napoleonic institutions. The addition of these controls does not affect the sign, magnitude or significance of the coefficient of interest (column 4).

Previous French Invasions Central Europe was plagued by continuous conflict following the creation of the Holy Roman Empire, and some areas in our sample had been repeatedly invaded by France before the Napoleonic wars. On the one hand, this could have forged a historical collective memory identifying France as the traditional enemy and Bonaparte as the villain insofar as he was the legitimate successor of the French kings. The rejection of French institutions could thus be driven by animosity originating

\footnotetext{
${ }^{55}$ According to Ellis (2003) ch. 3, Napoleon paid very little attention to primary education - especially for girls - while promoting technical training and higher education by establishing polytechnics, conservatories of art and trades, and lycées.
} 
from previous invasions rather than from cultural distance. ${ }^{56}$ On the other hand, protracted occupations could have improved the reception of new institutions, as they imply interactions with the French military and cultural exchanges with the local population. We construct a dummy variable that equals one if the area was occupied by French troops after the Peace of Westphalia (1648). The results suggest that previous French occupation does not systematically influence the adoption of the new institutional framework. Moreover, our main message is not affected by the introduction of this control variable, and the coefficients on Napoleon $\times$ Cultural dist remain negative and significant (column 5).

Severity of the Napoleonic Conflict An essential characteristic of the institutional transfer we examine is that it was forceful, often achieved through conquest, and carried out in one of the major theaters of the Napoleonic wars. If destruction from war has a persistent economic effect (longer than the 70-year period over which our dependent variable is constructed) and if harsher conflicts occurred in invaded culturally distant areas, then our results may be contaminated by the severity of the Napoleonic conflict. To control for this potential confounding factor, we collect data on all major battles during the Napoleonic military campaigns (1796-1815) and create a dummy variable that equals one if there was a relevant battle in the county. ${ }^{57}$ The results are robust to the inclusion of this additional control variable (column 6).

Religious and Linguistic Fragmentation Several papers have investigated the costs and benefits of diversity, whether racial, ethnic, religious, or linguistic (e.g., Alesina and La Ferrara, 2005). On the one hand, fragmented societies are more prone to poor policy management and pose more political economic challenges than do homogeneous societies. Accordingly, in counties characterized by high fragmentation, the functioning of French institutions could be impaired. On the other hand, a diverse cultural or ethnic mix may provide a variety of abilities and experiences that boost productivity through innovation and creativity. In this case, a highly fractionalized county may be a better recipient of French institutions. To test this alternative explanation, we construct and include in the baseline specification two different measures: a Herfindahl index using the shares of the three largest religious groups (Protestants, Catholics and Jews) and a similar index using the number of languages spoken in the county. ${ }^{58}$ We use these measures and their interactions with the Napoleonic dummy. The coefficients of these new controls are not systematically significant, and our main results are unchanged (column 7).

Summary Finally, in column (8), we implement a horse-race model, including all controls for the alterna-

\footnotetext{
${ }^{56}$ We did not find any anecdotal evidence that conflicts were harsher in Protestant areas or in specific linguistic regions. Rather, French invasions often involved the Catholic lands of the Rhenish area. For example, Trier was besieged and occupied by French troops three times between 1632 and 1675, and in 1673, the French military destroyed all its churches and abbeys.

${ }^{57}$ We define major battles as those with at least 1,000 deaths. Of a total of 23 battles, only 5 occurred in the counties included in our sample: Dennewitz in 1813 (approximately 30,000 casualties); Friedland in 1807 (30,000); Heilsberg in 1807 (7,400); Lutzen in $1813(31,000)$ and Eylau in $1807(40,000)$.

${ }^{58}$ The latter index is not weighted by population shares speaking a given language due to the lack of data.
} 
Table A7: Competing Explanations

\begin{tabular}{|c|c|c|c|c|c|c|c|c|}
\hline & $\begin{array}{c}\text { State } \\
\text { capacity }\end{array}$ & $\begin{array}{l}\text { Pre-Napoleonic } \\
\text { reforms }\end{array}$ & $\begin{array}{l}\text { Peripheral } \\
\text { ruler }\end{array}$ & $\begin{array}{l}\text { Educational } \\
\text { centers }\end{array}$ & $\begin{array}{c}\text { French } \\
\text { occupation }\end{array}$ & Battles & Fragmentation & Horserace \\
\hline $\begin{array}{l}\text { Log Average Wage Male } \\
\text { Elem. Teachers in } 1886\end{array}$ & (1) & (2) & (3) & (4) & (5) & (6) & (7) & (8) \\
\hline Napoleon & $\begin{array}{l}-0.591 \\
(0.829)\end{array}$ & $\begin{array}{l}-1.273 \\
(0.856)\end{array}$ & $\begin{array}{l}-0.809 \\
(0.948)\end{array}$ & $\begin{array}{l}-0.614 \\
(0.811)\end{array}$ & $\begin{array}{l}-1.031 \\
(0.884)\end{array}$ & $\begin{array}{l}-0.590 \\
(0.816)\end{array}$ & $\begin{array}{l}-0.706 \\
(0.816)\end{array}$ & $\begin{array}{l}-1.017 \\
(1.225)\end{array}$ \\
\hline Protestant Share & $\begin{array}{l}0.188^{* * *} \\
(0.0405)\end{array}$ & $\begin{array}{l}0.175^{* * *} \\
(0.0491)\end{array}$ & $\begin{array}{l}0.212^{* * *} \\
(0.0405)\end{array}$ & $\begin{array}{l}0.190^{* * *} \\
(0.0403)\end{array}$ & $\begin{array}{l}0.200^{* * *} \\
(0.0409)\end{array}$ & $\begin{array}{l}0.190^{* * *} \\
(0.0403)\end{array}$ & $\begin{array}{l}0.168^{* * *} \\
(0.0380)\end{array}$ & $\begin{array}{l}0.168^{* * *} \\
(0.0563)\end{array}$ \\
\hline Napoleon $\times$ Protestant Share & $\begin{array}{l}-0.205^{* * *} \\
(0.0427)\end{array}$ & $\begin{array}{l}-0.168^{* * *} \\
(0.0481)\end{array}$ & $\begin{array}{l}-0.241^{* * *} \\
(0.0434)\end{array}$ & $\begin{array}{l}-0.208^{* * *} \\
(0.0406)\end{array}$ & $\begin{array}{l}-0.218^{* * *} \\
(0.0398)\end{array}$ & $\begin{array}{l}-0.208^{* * *} \\
(0.0406)\end{array}$ & $\begin{array}{l}-0.179^{* * *} \\
(0.0385)\end{array}$ & $\begin{array}{l}-0.157^{* *} \\
(0.0659)\end{array}$ \\
\hline Church Ordinances & $\begin{array}{l}0.0452^{*} \\
(0.0230)\end{array}$ & & & & & & & $\begin{array}{l}0.0707^{* *} \\
(0.0313)\end{array}$ \\
\hline Nap $\times$ Church Ordinances & $\begin{array}{l}-0.0338 \\
(0.0360)\end{array}$ & & & & & & & $\begin{array}{l}-0.0413 \\
(0.0456)\end{array}$ \\
\hline Pre-Napoleonic Reforms. & & $\begin{array}{c}-0.261^{* * *} \\
(0.0560)\end{array}$ & & & & & & $\begin{array}{l}-0.245^{* * *} \\
(0.0822)\end{array}$ \\
\hline Nap $\times$ Reforms & & $\begin{array}{l}0.248^{* * *} \\
(0.0530)\end{array}$ & & & & & & $\begin{array}{l}0.241^{* * *} \\
(0.0784)\end{array}$ \\
\hline Peripheral Ruler & & & $\begin{array}{c}0.0833^{* * *} \\
(0.0273)\end{array}$ & & & & & $\begin{array}{l}0.0446 \\
(0.0809)\end{array}$ \\
\hline Napoleon $\times$ Peripheral Ruler & & & $\begin{array}{l}-0.0504^{*} \\
(0.0305)\end{array}$ & & & & & $\begin{array}{l}-0.00554 \\
(0.0804)\end{array}$ \\
\hline University in 1517 & & & & $\begin{array}{l}-0.0372 \\
(0.0312)\end{array}$ & & & & $\begin{array}{l}-0.0694 \\
(0.0868)\end{array}$ \\
\hline Nap $\times$ Universities & & & & $\begin{array}{c}0.0537 \\
(0.0461)\end{array}$ & & & & $\begin{array}{c}0.0949 \\
(0.0944)\end{array}$ \\
\hline Monasteries or Schools in HRE & & & & $\begin{array}{l}0.0957^{* *} \\
(0.0440)\end{array}$ & & & & $\begin{array}{c}0.000193 \\
(0.0372)\end{array}$ \\
\hline Napoleon $\times \%$ Monasteries or Schools in HRE & & & & $\begin{array}{l}-0.0613 \\
(0.0544)\end{array}$ & & & & $\begin{array}{c}0.0228 \\
(0.0511)\end{array}$ \\
\hline Previous French Presence & & & & & $\begin{array}{l}-0.0189 \\
(0.0830)\end{array}$ & & & $\begin{array}{l}0.0240 \\
(0.167)\end{array}$ \\
\hline Napoleon $\times$ Previous French Presence & & & & & $\begin{array}{c}0.0245 \\
(0.0896)\end{array}$ & & & $\begin{array}{l}-0.0111 \\
(0.169)\end{array}$ \\
\hline Battles & & & & & & $\begin{array}{c}-0.00493 \\
(0.0386)\end{array}$ & & $\begin{array}{l}0.00764 \\
(0.0378)\end{array}$ \\
\hline Nap $\times$ Battles & & & & & & $\begin{array}{r}-0.00909 \\
(0.0434)\end{array}$ & & $\begin{array}{l}-0.00407 \\
(0.0517)\end{array}$ \\
\hline Religious Fragmentation & & & & & & & $\begin{array}{l}0.141^{* *} \\
(0.0605)\end{array}$ & $\begin{array}{l}0.0460 \\
(0.0965)\end{array}$ \\
\hline Napoleon $\times$ Religious Fragmentation & & & & & & & $\begin{array}{l}-0.155^{* *} \\
(0.0763)\end{array}$ & $\begin{array}{l}-0.0657 \\
(0.111)\end{array}$ \\
\hline Linguistic Fragmentation & & & & & & & $\begin{array}{r}-0.00525 \\
(0.0510)\end{array}$ & $\begin{array}{c}0.0236 \\
(0.0349)\end{array}$ \\
\hline Nap $\times$ Linguistic Fragmentation & & & & & & & $\begin{array}{c}0.0218 \\
(0.0771)\end{array}$ & $\begin{array}{l}-0.0226 \\
(0.0677)\end{array}$ \\
\hline$R^{2}$ & 0.678 & 0.716 & 0.676 & 0.680 & 0.667 & 0.677 & 0.682 & 0.725 \\
\hline Obs. & 447 & 427 & 429 & 447 & 429 & 447 & 447 & 427 \\
\hline
\end{tabular}

Notes: The column headings indicate the alternative channel we investigate in the specification. The dependent variable is the logarithm of the average annual wage of an elementary school teacher in 1886. All specifications include Geographic Controls, Historical Controls, Socioeconomic Controls, Education Controls and Hist $\mathcal{E}$ Geo Interactions. See also the notes to Table 3. The complete table can be found in the Appendix. Robust standard errors are in parentheses.

${ }_{* * *} \mathrm{p}<0.01,{ }^{* *} \mathrm{p}<0.05,{ }^{*} \mathrm{p}<0.1$

tive explanations. Our main results survive this demanding exercise. These findings confirm that despite complex interactions among institutions and historical and socioeconomic factors, cultural similarity does play a role in institutional transplants and long-term economic outcomes. 


\section{Baseline Specification on Invaded Territories}

In this section we perform a sensitivity analysis using only the subsample of counties that were under the Napoleonic rule. This exercise is meant to isolate the effect of cultural proximity within the invaded areas. To this purpose, we estimate variations of the following model:

$$
y_{i}=\alpha+\beta_{1} \text { Cultural dist }_{i}+\mathbf{H}_{i} \beta_{4}+\mathbf{G}_{i} \beta_{5}+\mathbf{E}_{i} \beta_{6}+\mathbf{X}_{i} \beta_{7}+\varepsilon_{i}
$$

where $y_{i}$ is the $\log$ of the average income of male elementary school teachers in county $i$; Cultural dist $_{i}$ is the measure of cultural distance; $\mathbf{H}_{\mathbf{i}}, \mathbf{G}_{\mathbf{i}}, \mathbf{E}_{\mathbf{i}}$ and $\mathbf{X}_{\mathbf{i}}$ are vectors of historical, geographical, educational and socioeconomic controls, respectively; and $\varepsilon_{i}$ is an error term. We report results using three different measures of cultural distance from France: the Protestant share in the county population; a linguistic distance measure, and a dummy capturing the cultural links between Pre-Napoleonic German and French elites (See Section for the definition of the variables).

First, we focus on our main proxy of cultural distance, the Protestant share in the county population. Moving along columns the set of controls increases. Results suggest that the Protestant share is not systematically associated with economic outcomes. This result is quite surprising and in contrast with the existing literature (e.g. Becker and Woessmann, 2009) which finds that Protestantism had a strong positive impact on economic development. Indeed, throughout the analysis the average effect of the Protestant share have been consistently positive and precisely estimated. In fact, if we were perform the analysis only in the subsample of territories not invaded by Napoleon, the effect of the Protestant share is positive, significant and three times as large as the one found in column (3). This evidence is in line with our baseline results, and it suggests that the effects of French institutions negatively interacts with local culture by reducing the positive effect of Protestantism on economic growth.

In the remaining columns, we reestimate eq. (4) using alternative proxies of cultural distance. Columns (4)-(6) present the result using linguistic distance. Consistently with the baseline results, cultural distance is negatively associated with economic performances in the invaded territories. This evidence is also confirmed by the results in columns (7)-(9), where we repeat the analysis using the No French Ties variable. Overall the result of this sensitivity test corroborate our baseline evidence, and further suggest that territories that received the Napoleonic institutions were disadvantaged if they were culturally distant from France. 
Table A8: Effect of Culture in Territories under Napoleonic Rule

\begin{tabular}{|c|c|c|c|c|c|c|c|c|c|}
\hline $\begin{array}{l}\text { Log Average Wage Male } \\
\text { Elem. Teachers in } 1886\end{array}$ & (1) & $(2)$ & (3) & (4) & (5) & (6) & (7) & (8) & (9) \\
\hline Protestant Share & $\begin{array}{c}0.0226 \\
(0.0262)\end{array}$ & $\begin{array}{c}0.0315 \\
(0.0262)\end{array}$ & $\begin{array}{l}0.0767^{* *} \\
(0.0310)\end{array}$ & & & & & & \\
\hline Ling. Dist & & & & $\begin{array}{c}-0.0040^{* * *} \\
(0.00061)\end{array}$ & $\begin{array}{c}-0.0043^{* * *} \\
(0.0006)\end{array}$ & $\begin{array}{l}-0.0024^{* * *} \\
(0.00059)\end{array}$ & & & \\
\hline No French Ties & & & & & & & $\begin{array}{c}-0.0589^{* * *} \\
(0.0215)\end{array}$ & $\begin{array}{c}-0.0783^{* * *} \\
(0.0202)\end{array}$ & $\begin{array}{c}-0.0442^{* * *} \\
(0.0163)\end{array}$ \\
\hline Geographic Controls & yes & yes & yes & yes & yes & yes & yes & yes & yes \\
\hline Historical Controls & no & yes & yes & no & yes & yes & no & yes & yes \\
\hline Economic Controls & no & no & yes & no & no & yes & no & no & yes \\
\hline Education controls & no & no & yes & no & no & yes & no & no & yes \\
\hline$R^{2}$ & 0.431 & 0.458 & 0.750 & 0.452 & 0.481 & 0.750 & 0.448 & 0.485 & 0.750 \\
\hline Obs. & 238 & 238 & 238 & 238 & 238 & 238 & 238 & 238 & 238 \\
\hline
\end{tabular}

Notes: The analysis is performed only on the subsample of the territories under Napoleonic rule. Territories under Napoleonic rule are defined as both French empire and Satellite state (dummy Napoleon equal to 1). See also the notes to Table 4 for the definitions of the controls. Robust standard errors in parentheses.

*** $\mathrm{p}<0.01,{ }^{* *} \mathrm{p}<0.05,{ }^{*} \mathrm{p}<0.1$ 


\section{B APPENDIX - DATA}

\section{Linguistic Regions}

For the baseline measure, all the counties in the dataset are mapped into 35 different linguistic regions according to Ethnologue database classification. The languages we identify are: Armenian, Alemannic, Bavarian, Belarusian, Czech, Danish, Frisian, Northern, German, Standard, Kashubian, Limburgish, Lithuanian, Luxembourgish, Palatinate Franconian, Plautdietsch, Polish, Prussian, Ripuarian, Romani, Baltic, Romani, Carpathian, Russian, Rusyn, Saterfriesisch, Saxon, East Frisian Low, Saxon, Low, Saxon, Upper, Silesian, Silesian, Lower, Sorbian, Lower, Sorbian, Upper, Swabian, Ukrainian, Westphalien, Wymysorys, Yeniche.

For the ancestral distance measure instead, the counties in the sample are mapped into 23 different linguistic regions according to the a detailed map of the ancestral languages provided at http:/ / www.muturzikin.com/carte and dialects of Europe as in Spolaore and Wacziarg (2014). The map includes only native languages, discarding languages spoken by migrants. We end up with 39 clusters of counties speaking the same ancestral languages. Each cluster is composed by counties speaking the same combination of the 23 languages (i.e. the counties of Fulda and Erfurt are home to two ancestral languages Upper Saxon and Eastern Franconian, hence they belonterg to the same cluster). The ancestral languages we identify are: Aachterhoeks, Kashubian, Danish, German Standard, Drents, French, Northern Frisian, Frisian, Gronings, Upper Sorbian, Limburgish, Lithuanian, Low Saxon, Dutch, Palatinate Franconian, Polish, Rusyn, Sallands, Samogitian, Swabian, Upper Saxon, Silesian and Eastern Franconian.

\section{Linguistic Variable Construction}

To construct the linguistic distance measure, we first exploit the linguistic information reported in the Ethnologue database, which describes the languages that are currently spoken in each NUTS2 region. We map the county of our dataset to the current NUTS2 region and attribute to the county all the languages spoken in that region. We define the linguistic distance metrics as the average linguistic distance of the languages spoken in a given county, in the same spirit of Fearon (2003) and Desmet et al. (2009). The distance metric between language $j$ and $f$ is: ${ }^{59}$

$$
d_{j f}=1-\left(\frac{l_{j f}}{m_{j f}}\right)^{\delta}
$$

\footnotetext{
${ }^{59}$ The variable $d_{j f}$ takes values in the unit interval. We rescale $d_{j f}$ to take values in $[0,100]$.
} 
where $l$ is the number of shared branches between $j$ and $f, m$ is the maximum number of branches between the two languages, and $\delta$ is a parameter that determines how fast the distance declines as the number of shared branches increases. ${ }^{60,61}$

To construct the alternative linguistic measure, we follow Spolaore and Wacziarg (2014) and exploit a detailed map of the ancestral languages and dialects of Europe and match every language in the source map to the corresponding counties in our dataset. ${ }^{62}$ We end up with 23 ancestral languages matched to each of the 447 counties. ${ }^{63}$ Then, for each ancestral language, we use the linguistic classification from the Ethnologue to compute the linguistic distance of each language from the French spoken in Paris.

\section{Pre-Napoleonic Principalities}

All the counties in the dataset are mapped into 36 different principalities belonging to the Holy Roman Empire, the Kingdom of Prussia and the Kingdom of Poland. We refer to the political situation in 1789. The principalities we identify are: Austrian Netherlands, Bishopric of Cologne, Bishopric of Fulda, Bishopric of Hildesheim, Bishopric of Munster, Bishopric of Osnabruck, Bishopric of Paderborn, Bishopric of Trier, County of Mark, County of Hohenzollern-Sigmaringen, County of Lingen, County of Nassau, County of Nassau-Saarbrucken, Duchy of Berg, Duchy of Brunswick-Wolfenbuttel, Duchy of Cleves, Duchy of Julich, Duchy of Oldenburg, Duchy of Schleswig-Holstein, Duchy of Weimar, Duchy of Westphalia, East Frisia, Electoral Palatinate, Electorate of Brandeburg, Electorate of Brandenburg - County of Ravensberg, Electorate of Brandenburg - Kingdom of Prussia, Electorate of Brandenburg - Lower Silesia, Electorate of Brandenburg - Pomerania, Electorate of Brandenburg - Principality of Minden, Electorate of Hanover, Electorate of Mainz, Electorate of Saxony, Landgraviate of Hesse-Kassel, Palatinate-Zweirbrucken, Polish-Lithuanian Commonwealth and Swedish Pomerania Provinces. Finally some autonomous cities were classified as Imperial or Independent cities.

\footnotetext{
${ }^{60}$ In the baseline specification, we set $\delta=0.05$ as suggested by Desmet et al. (2009). All our results (available upon request) are robust when using other values for $\delta \in(0,1]$.

${ }^{61}$ For instance, French is classified as: Indo-European - Italic - Romance - Italo-Western - Western- GalloIberian - Gallo-Romance - Gallo-Rhaetian - Oil - Francais, while the classification for Standard German is Indo-European - Germanic - West - High German - German - Middle German- East Middle German German Standard. They share 1 node on a maximum of 17 nodes. Hence, fixing $\delta=0.05$, the distance between the two languages is 0.132 .

${ }^{62} \mathrm{As}$ in Spolaore and Wacziarg (2014), the source for the language data is the map provided at http://www.muturzikin.com/carteeurope.htm. The map includes only native languages and discards languages spoken by migrants.

${ }^{63}$ The different combinations of languages spoken in a county generate 39 language clusters. For instance, the counties of Fulda and Erfurt are home to two ancestral languages, Upper Saxon and Eastern Franconian; hence, they belong to the same cluster.
} 


\section{Pre-Napoleonic Rulers: No French Ties}

We identified rulers from different sources, the time span we consider is 1701-1790. For example, the Bishopric of Hildesheim had 5 rulers in this period: Jobst Edmund von Brabeck, Joseph Clemens of Bavaria, Clemens August, Friedrich Wilhelm von Westphalen and Franz Egon von Fürstenberg. Among all these rulers only Joseph Clemens of Bavaria had at least one french direct relative. His mother was the Princess Louise Victoire d'Orléans-Alençon. Joseph Clemens of Bavaria allied with France during the War of Spanish Succession and found refuge at the French court after the war. In this principality No French Ties has been coded as 0 .

\section{Church Ordinances}

We identified 45 church ordinances in the following Prussian counties: Anklam, Aschersleben (2), Berlin, Celle, Danzig, Delitzsch, Dortmund, Einbeck, Emden, Erfurt, Frankfurt am Main, Gottingen, Gelnhausen, Greifswald, Halberstadt, Hanau, Hannover, Hildesheim, Jerichow I, Kassel, Luneburg, Liebenburg, Magdeburg, Marburg, Merseburg (2), Naumburg, Nordhausen, Osnabruck, Ost-Havelland, Potsdam, Prenzlau, Ruppin, Salzwedel, Siegen, Stader Geest, Stendal, Stettin, Tecklenburg, Torgau, Weissenfels, West-Havelland, Wetzlar, Wittenberg. 
Pre-Napoleonic Principalities Aggregated by Ruler

No French Ties Pre-Napoleonic Reforms

Duchy of Berg, Duchy of Julich and Electorate Palatinate

Electorate of Brandeburg ${ }^{a}$, Duchy of Cleves, County of Mark, County of Lingen

Austrian Netherlands

Bishopric of Munster

Bishopric of Cologne, Duchy of Westphalia

Bishopric of Osnabrück

Bishopric of Paderborn

County of Nassau

Principality of Nassau Saarbrücken

East Frisia

Electorate of Mainz

Electorate of Trier

Electorate of Saxony and Polish Lithuanian Commonwealth (since 1764)

Electorate of Saxony

Duchy of Weimar

Duchy of Brunswick-Wolfenbüttel

Bishopric of Hildesheim

Landgraviate of Hesse-Kassel and Swedish Pomerania Province

Bishopric of Fulda

Electorate of Hanover

Duchy of Schleswig-Holstein

$\begin{array}{ll}0 & 0 \\ 0 & 1 \\ 0 & 0 \\ 1 & 1 \\ 0 & 1 \\ 1 & 0 \\ 1 & 1 \\ 0 & 1 \\ 0 & 1 \\ 1 & 1 \\ 1 & 1 \\ 0 & 0 \\ 0 & 1 \\ 0 & 0 \\ 1 & 1 \\ 1 & 1 \\ 0 & 1 \\ 0 & 1 \\ 1 & 1 \\ 1 & 0 \\ 1 & 0\end{array}$

${ }^{a}$ Throughout the paper we divide the territories of the Electorate of Brandeburg in six different areas according to the timing of the Prussian expansion. 